\title{
Textual interrelationships involving the Septuagint translations of the precious stones in the breastpiece of the high priest
}

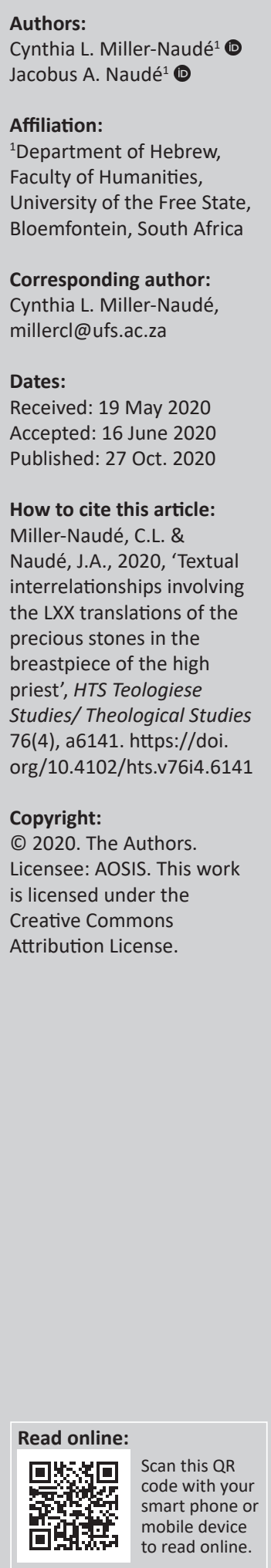

The Hebrew Bible mentions 12 precious stones arranged in four rows of three each on the high priest's breastpiece in two lists (Ex 28:17-20 and 39:10-13). Nine of these precious stones reappear in the Tyrian king's 'covering' in Ezekiel 28:13 in three groups of three. Although the two lists in Exodus are identical, the order in Ezekiel is slightly different. In Septuagint (LXX) Ezekiel there are 12 precious stones. However, the number and order in the LXX lists (LXX-Ex 28:17-20 and 36:17-20; LXX-Ezk 28:13) are constant in all three cases. The same 12 stones as in the LXX appear, but with variation in order, in two accounts found in Josephus (The Wars of the Jews Book 5, Chapter 5, Section 7; The Antiquities of the Jews Book 3, Chapter 7, Section 5). The list of precious stones in Revelation 21:19-20 that adorn the 12 foundations of the New Jerusalem is reminiscent of the breastpiece, but it shows four new names along with eight that are known from the LXX; it is not clear if it is a fresh translation from the Hebrew list. This article focuses on the relationships amongst these lists by examining the arrangement, translation and symbolism of these precious stones.

Contribution: The precious stones in the high priest's breastpiece (Exod 28:17-20, 39:10-13) were rendered differently and re-arranged by the Septuagint and other later versions for new contexts, audiences and theological purposes. Unknown stones were rendered with similar stones known to the translator or the incipient text terms were transliterated.

Keywords: Septuagint; High priest breastpiece; Masoretic Text; Vulgate; Syriac; Targumim; Josephus; Translation strategy; Coordination; Greek syntax.

\section{Introduction}

The Hebrew Bible mentions 12 precious stones arranged in four rows of three each on the high priest's breastpiece in two identical lists in Exodus 28:17-20 and 39:10-13. Nine of these precious stones reappear in the Tyrian king's 'covering' in Ezekiel 28:13 in three groups of three, although the order is slightly different from Exodus. In the Septuagint (LXX) version of Exodus, the same 12 precious stones appear, but with a variation in their order. In the LXX version of Ezekiel, there are 12 precious stones, rather than nine as in the Hebrew, and the order of stones in LXX-Ezekiel is identical to that in LXX-Exodus. Josephus has two accounts of the breastpiece of the high priest in The Wars of the Jews (Book 5, Chapter 5, Section 7) and The Antiquities of the Jews (Book 3, Chapter 7, Section 5). In those two accounts, the same 12 stones appear as are found in the LXX with slight variations in spelling but with variation in the order. The list of precious stones in Revelation 21:19-20 that adorn the 12 foundations of the New Jerusalem is reminiscent of the breastpiece, but shows four new names along with the eight that are known from the LXX. This article focuses on the relationships amongst these lists by examining the arrangement, translation and symbolism of these precious stones in Exodus, Ezekiel, Josephus and Revelation. The methodology employed will be editorial theory and complexity theory; this article thus continues the research agenda of applying translation studies and editorial theory to ancient translations as exemplified in MillerNaudé and Naudé (2018), Naudé and Miller-Naudé (2018, 2019, forthcoming) and Naudé, MillerNaudé and Makutoane (forthcoming).

The outline of the article is as follows. The following sections discuss the lists of precious stones in the Hebrew lists (Ex 28:17-20, 39:10-13; Ezk 28:13), the LXX (Ex 28:17-20, 36:17-20; Ezk 28:13), the Vulgate, the Syriac, the targumim, Josephus and Revelation 21:19-20. ${ }^{1}$ An analysis of the translations considered. 
arrangement of the lists and their interrelationships follows. The final section presents our conclusions. ${ }^{2}$

\section{The Hebrew lists}

\section{The breastpiece of the high priest (Ex 28:17-20, 39:10-14)}

The precious stones in the breastpiece of the high priest are described in Exodus 28:17-20 and 39:10-14. ${ }^{3}$ The Hebrew texts explicitly specify the order of the stones in each of the four rows. The fourfold divisions of the lists are also covertly indicated by the presence of bisyllabic nouns at the end of the first three rows (Reader 1981:436-437). Contrast the use of the trisyllabic noun ברְְ (Ex 28:17; 39:10) with the bisyllabic biform רכָרקת in Ezekiel 28:13; in the Ezekiel list, trisyllabic nouns do not mark the ends of rows.

The stones are explicitly said to represent the 12 tribes of Israel symbolically and are each engraved with one of the names of the 12 tribes (Ex 28:21; 39:14). In both of the lists, the names of the stones are identical, and the arrangements of the stones within the four rows are identical.

There are two minor grammatical differences between the two Exodus lists. The first grammatical difference relates to the patterns of coordination in the final row. Each of the first three rows of three stones has 'final coordination' in which waw occurs only before the final stone in the row. However, the two lists diverge with respect to coordination in the fourth row - Exodus 28:20 exhibits 'multiple coordination', in which conjunctive waw occurs before each conjunct after the first one (i.e. the second and third stones), whereas Exodus 39:13 exhibits only final coordination before the third stone, following the pattern of the first three rows. ${ }^{4}$ Multiple coordination of noun phrases in which the second and all subsequent items are explicitly coordinated (as in row 4 of Ex 28:20) is more common in the Hebrew Bible; the use of only final coordination (as in rows 1-3 of both lists and row 4 of Ex 39:13) is less common (Waltke \& O'Connor 1990:648). These features are summarised in Table 1.

The second grammatical difference relates to the use of a finite form of the copular verb twice in Exodus 28:21

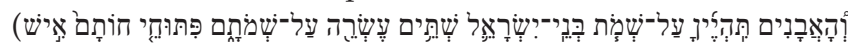
[The stones shall be according to the names of the sons of Israel ... Engravings of seals, each one according to its name they will be according to the names of the 12 tribes]). By contrast, in Exodus 39:14, the copular verb is omitted (or covert), and there are two verbless sentences. In all other respects, the two verses are identical.

The MT does not indicate two crucial matters concerning the arrangement of the stones. Firstly, the direction of

2.The following abbreviations are used: A, Josephus' Antiquities; LXX, Septuagint; MT, Masoretic Text; N, Targum Neofiti; O, Targum Onqelos; PJ, Targum Pseudo-Jonathan $\mathrm{S}$, Syriac; SP, Samaritan Pentateuch; V, Vulgate; W, Josephus' War.

3.The Hebrew text used throughout is from the Biblia Hebraica Stuttgartensia (1997).

4.The terminology 'final coordination' and 'multiple coordination' are from Scheumann (forthcoming).
TABLE 1: MT-Exodus 28:17-20 and MT-Exodus 39:10-14.

\begin{tabular}{|c|c|c|c|c|c|}
\hline \multirow{2}{*}{$\begin{array}{l}\text { Rows } \\
\text { (both lists) } \\
1\end{array}$} & \multirow{2}{*}{$\begin{array}{l}\text { Syllable structure of terms } \\
\text { (both lists) }\end{array}$} & \multicolumn{2}{|c|}{$\begin{array}{l}\text { MT-Exodus } \\
28: 17-20\end{array}$} & \multicolumn{2}{|c|}{$\begin{array}{l}\text { MT-Exodus } \\
39: 10-14\end{array}$} \\
\hline & & 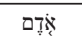 & - & 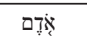 & - \\
\hline & Bisyllabic & פָטְדָדה & - & פְּטְָדָה & - \\
\hline & Trisyllabic & וּבְרָקֶקת & waw & וּבדרֶּקת & waw \\
\hline \multirow[t]{3}{*}{2} & Bisyllabic & 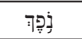 & - & נִפֶֶד & - \\
\hline & Bisyllabic & סַפְּיר & - & סַפְּיר & - \\
\hline & Trisyllabic & וּיָהלםם & waw & 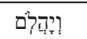 & waw \\
\hline \multirow[t]{3}{*}{3} & Bisyllabic & לֶשֶםם & - & לֶשֶםם & - \\
\hline & Bisyllabic & שָָָׁוֹ & - & שֶׁבְו & - \\
\hline & Trisyllabic & וֹאַחְלָלָה & waw & 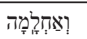 & waw \\
\hline \multirow[t]{3}{*}{4} & Bisyllabic & תַּרְשׁׁיש & - & תַּרְשׁׁיש & - \\
\hline & Bisyllabic & וְשׁׁהםם & waw & שֶׁהם & - \\
\hline & Bisyllabic & 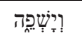 & waw & 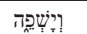 & waw \\
\hline
\end{tabular}

MT, Masoretic Text.

arrangement of the stones is not clear, namely, whether the list of stones in each row relates to an arrangement from right to left or from left to right. The fact that each stone has the name of one of the tribes engraved on it like a seal does not settle the question definitively. The direction of writing of the earliest Canaanite script was variable, as illustrated by the presence at the single site of Khirbet Qeiyafa of right-to-left writing on an incised ostracon (Garfinkel et al. 2015) as well as left-to-right writing on another ostracon (Misgav, Garfinkel \& Ganor 2009). The direction of writing was later standardised with the Phoenician script, which exhibited right-to-left writing. Secondly, it is not clear the order in which the names of the 12 tribes appear; the names are explicitated in two different ways in two of the targumic translations, as discussed below (see also Amar 2016).

The SP is very close to the MT. ${ }^{5}$ In both passages, the stones are identical to those of the MT, and their arrangement within rows is identical to the MT. In SP-Exodus 28:20, the coordination pattern involves only final coordination as in MT-Exodus 39:10-14. In other words, both passages are identical in this regard in the SP; it seems likely that the SP has harmonised the coordination patterns of the two passages. There are other minor differences between the SP and the MT in this passage, specifically involving the precise description of the setting of the stones on the breastpiece (SP-Ex 28:17, 20; SP-Ex 39:8-9) and an alternation between third-person singular and plural to describe the individual(s) who fabricated the breastpiece (SP-Ex 39:8-9).

\section{The covering of the king of Tyre (Ezk 28:13)}

In Ezekiel 28:13, the dirge over the king of Tyre includes a description of his adornment with a 'covering' of precious stones that is similar, but not identical, to that of the breastpiece of the high priest (Table 2):

A comparison of the Ezekiel list with the Exodus lists shows that Exodus list has been modified in Ezekiel in the following ways: Firstly, row 3 is entirely deleted (Table 3).

Secondly, row 4 is moved up between rows 1 and 3 to become row 2 (Table 4 ).

5.The text used for the SP is Von Gall (1918). 
TABLE 2: MT-Ezekiel 28:13

\begin{tabular}{|c|c|c|c|}
\hline Column 3 & Column 2 & Column 1 & \\
\hline רוּיָהלם & 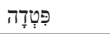 & אדֶֶ & Row 1 \\
\hline רוּישֵׁפהּה & שה & תַרְּשׁיש & Row 2 \\
\hline וּרָרְּקת & נפקֶּ & סַפְּיר & Row 3 \\
\hline
\end{tabular}

TABLE 3: Modification of MT-Exodus list in MT-Ezekiel - Deletion of row 3.

\begin{tabular}{|c|c|c|c|}
\hline Column 3 & Column 2 & Column 1 & \\
\hline וּבָרְקְת & פְְִּדָדה & אדֶָם & Row 1 \\
\hline וּיָהָלםם & סַפְּיר & נפכֶך & Row 2 \\
\hline 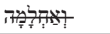 & ن & לֶ? & Row 3 \\
\hline 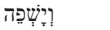 & וְשׁהַם & תַרְּשׁיש & Row 4 \\
\hline
\end{tabular}

TABLE 4: Modification of MT-Exodus list in MT-Ezekiel - Movement of row 4 to row 2.

\begin{tabular}{|c|c|c|c|}
\hline Column 3 & Column 2 & Column 1 & \\
\hline וּרָרְקָת & פְְִּדָה & אדֶד & Row 1 \\
\hline 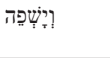 & שהםם & 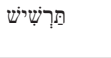 & $\begin{array}{l}\text { Row } 2 \\
\text { (= row } 4 \text { in Exodus) }\end{array}$ \\
\hline רוּיָהלם & סַפְּיר & נפקֶּ & $\begin{array}{l}\text { Row } 3 \\
\text { (= row } 2 \text { in Exodus) }\end{array}$ \\
\hline
\end{tabular}

TABLE 5: Modification of MT-Exodus list in MT-Ezekiel - Two pairs of exchanges.

\begin{tabular}{|c|c|c|c|}
\hline Column 3 & Column 2 & Column 1 & \\
\hline & & אדֶד & Row 1 \\
\hline & שהםם & תַרְשׁׁיש & $\begin{array}{l}\text { Row } 2 \\
(=\text { row } 4 \text { in MT-Ex) }\end{array}$ \\
\hline & סַפְּיר & נפקֶּד & $\begin{array}{l}\text { Row } 3 \\
\text { (= row } 2 \text { in MT-Ex) }\end{array}$ \\
\hline
\end{tabular}

Note: Grey highlighting indicates the stones that correspond across the lists.

MT, Masoretic Text.

Thirdly, and finally, the first and last stones in column 3 ברְקָת and יניָּלם

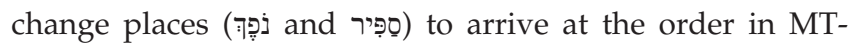
Ezekiel (Table 5).

It is impossible to know precisely why the 12 stones arranged in a rectangular pattern of four rows with three stones each in the breastpiece of the high priest were altered to nine stones in a square pattern of three rows with three stones each. However, one possibility is to avoid attributing to the king of Tyre the high priest's breastpiece with its symbolic representation of the 12 tribes of Israel. ${ }^{6}$ What is striking about the arrangement of the stones in Ezekiel is the fact that the nine stones form a perfect square of eight stones, three on each side, around a centre stone, the onyx (שنהם).

\section{The Septuagint lists}

The LXX translation of all three passages reveals 12 stones in precisely the same order in all three passages (Table 6). ${ }^{7}$

6.An analogous situation occurs in LXX-Ezekiel 27:5-6, 31:3, 31:8, LXX-Job 40:17 in

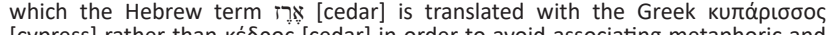

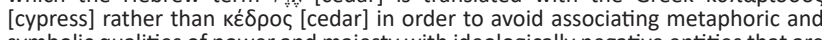
symbolic qualities of power and majesty with ideologically negative entities that are described with the term in the Hebrew text (Miller-Naudé \& Naudé 2018; Naudé $\&$ Miller-Naudé 2018). 7.The primary text edition used for the Septuagint of Exodus is Wevers (1991) with
comparison to Rahlfs and Hanhart (2006) and Brooke and McLean (1909). For the Septuagint of Ezekiel, Ziegler (2006) and Rahlfs and Hanhart (2006) For the Sept
are used.
TABLE 6: LXX translation of MT lists.

\begin{tabular}{|c|c|c|c|}
\hline & $\begin{array}{l}\text { MT-Exodus 28:17-20, } \\
\text { MT-Exodus 39:10-14 }\end{array}$ & $\begin{array}{l}\text { LXX-Exodus 28:17-20, } \\
\text { LXX-Exodus 36:17-20; } \\
\text { LXX-Ezekiel 28:13 }\end{array}$ & MT-Ezekiel 28:13 \\
\hline \multirow[t]{3}{*}{ Row 1} & םדֶ א & 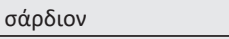 & 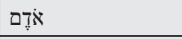 \\
\hline & 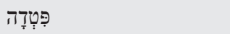 & 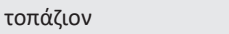 & 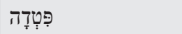 \\
\hline & וּרָרָרקת & 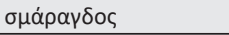 & וְיְהָלם \\
\hline \multirow[t]{3}{*}{ Row 2} & נפקֶ & $\alpha \ddot{v} \theta \rho \alpha \xi$ & תַּרְשׁיש \\
\hline & סַפְּיר & 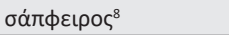 & שההם \\
\hline & רויניהלם & 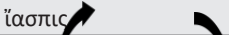 & וְיְשׁפַה \\
\hline \multirow[t]{3}{*}{ Row 3} & לֶשֶׁ & 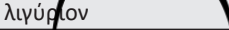 & סַפְּיר \\
\hline & שׁَבוֹ & 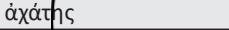 & נפכְקד \\
\hline & 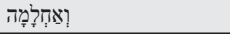 & 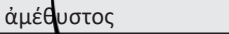 & וּבְרָקת \\
\hline \multirow[t]{3}{*}{ Row 4} & תמרְשׁׁיש & xpuodpiөos & \\
\hline & וְוֹשהם & Bnpústov & \\
\hline & רוּשְַָָׁה & óvúx & \\
\hline
\end{tabular}

Note: Grey shading indicates the stones that correspond across the lists. MT, Masoretic Text; LXX, Septuagint.

TABLE 7: LXX correlations to MT stones in Exodus.

\begin{tabular}{|c|c|c|c|}
\hline Column 3 & Column 2 & Column 1 & \\
\hline 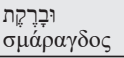 & 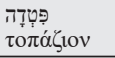 & 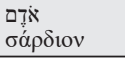 & Row 1 \\
\hline is & бám & 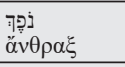 & Row 2 \\
\hline 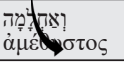 & 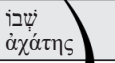 & 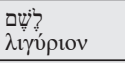 & Row 3 \\
\hline 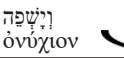 & 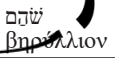 & 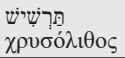 & Row 4 \\
\hline
\end{tabular}

Note: Grey shading indicates the stones that correspond across the lists.

The order of the stones in LXX-Exodus clearly differs in three instances from that in MT-Exodus. ${ }^{9}$ This is especially

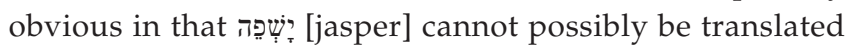

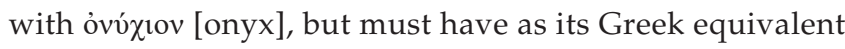

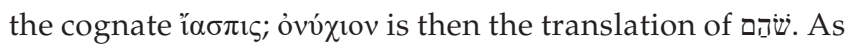
described in Naudé and Miller-Naudé (2020), the referent of יָדָל is 'aquamarine', a stone in the beryl family that is turquoise in colour. The LXX translator(s) does not have a

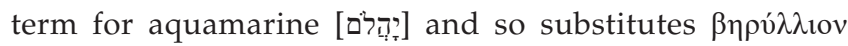
[beryl] as their rendering. Beryl is related to aquamarine and is blue-green; it is first known in Hellnistic times. With these adjustments, the stones in MT-Exodus and LXXExodus can be correlated as referring to the same stones (at least in appearance); the two lists are not entirely separate (contra Harrell 2001; Harrell, Hoffmeier \& Williams 2017).

Table 7 shows the correlations of the LXX translations to the MT within the rows of the breastpiece. The problematic correlations occur on the left edge and bottom edge of the breastpiece; the correct translations can be obtained by rotating the LXX terms in a counter-clockwise direction. The

8.In the two Exodus passages, this word is spelled oór it is spelled бór фіроৎ (see Walters 1973:36 for this alternation).

9.An anonymous reviewer suggests that perhaps the LXX order of precious stones is older than the order found in the Hebrew Bible. Of the three Hebrew texts, only Exodus 39:10-14 is partially attested at Qumran, albeit in a very broken text; see Ulrich (2013, 1:104-105). However, the fact that the SP lists the same stones in the same order as the MT in both Exodus passages as well as the lack of any scribal variants in the Hebrew textual traditions suggests that the Hebrew is original and the LXX is a translation. Futhermore, to understand the LXX as harmonising the order of the stones in the three texts relates to a cross-linguistic feature of translations; the opposite explanation (that the Hebrew changes the original orde reflected in the LXX in three places and shortens the list in Ezekiel) does not have any textual explanation. 
TABLE 8: MT, SP and LXX coordination patterns.

\begin{tabular}{|c|c|c|c|c|c|c|c|c|}
\hline & \multirow{2}{*}{$\begin{array}{l}\text { MT-Exodus } \\
28: 17-20\end{array}$} & \multicolumn{3}{|c|}{ LXX-Exodus 28:17-20 } & \multirow{2}{*}{$\begin{array}{l}\text { MT-Exodus 39:10-14 } \\
\text { SP-Exodus 28:17-20; } \\
\text { SP-Exodus 39:10-14 }\end{array}$} & \multirow{2}{*}{$\begin{array}{l}\text { LXX-Exodus 36:17-20 } \\
\text { Rahlfs-Hanhart (2006) } \\
\text { Wevers (1991) } \\
\text { Vaticanus } \\
\text { Alexandrinus }\end{array}$} & \multirow[t]{2}{*}{ MT-Ezekiel 28:13 } & \multirow{2}{*}{$\begin{array}{l}\text { LXX-Ezekiel 28:13 } \\
\text { Ziegler (2006) } \\
\text { Rahlfs-Hanhart } \\
\text { (2006) }\end{array}$} \\
\hline & & $\begin{array}{l}\text { Alexandrinus; } \\
\text { Wevers (1991) }\end{array}$ & $\begin{array}{l}\text { Vaticanus; Brooke and } \\
\text { McLean (1909) }\end{array}$ & $\begin{array}{l}\text { Rahlfs Hanhart } \\
\text { (2006) }\end{array}$ & & & & \\
\hline \multirow[t]{2}{*}{1} & - & - & - & - & - & Kai & - & kai \\
\hline & waw & - & kai & kai & waw & $K a i$ & waw & kai \\
\hline \multirow[t]{3}{*}{2} & - & - & - & - & - & - & - & kai \\
\hline & - & kai & kai & kai & - & kai & - & kai \\
\hline & waw & kai & kai & kai & waw & kai & waw & kai \\
\hline \multirow[t]{3}{*}{3} & - & - & - & - & - & - & - & kai \\
\hline & - & kai & - & - & - & kai & - & kai \\
\hline & waw & kai & - & kai & waw & kai & waw & kai \\
\hline \multirow[t]{3}{*}{4} & - & - & - & - & - & - & & $k a i$ \\
\hline & waw & kai & kai & kai & - & kai & & kai \\
\hline & waw & kai & $k a i$ & kai & waw & kai & & kai \\
\hline
\end{tabular}

MT, Masoretic Text; SP, Samaritan Pentateuch; LXX, Septuagint.

covering of the king of Tyre in MT-Ezekiel also exhibited alterations from MT-Exodus on the left and bottom edges (Table 5).

A comparison of the coordination patterns of the MT, SP and selected LXX texts is also instructive (Table 8). Masoretic Text Exodus 28:17-20 varies the pattern of final coordination only in row 4, which has multiple coordination. The Septuagint texts of LXX-Exodus 28:17-20 exhibit variation with respect to coordination. Vaticanus, followed by Brooke and McLean (1909), has final coordination in row 1, multiple coordination in row 2 , no coordination in row 3 and multiple coordination in row $4 . .^{10}$ Alexandrinus, followed by Wevers (1991), has no coordination in row 1 and multiple coordination in rows 2, 3 and 4. Rahlfs and Hanhart (2006) alternate final coordination (rows 1 and 3) with multiple coordination (rows 2 and 4). In LXX-Exodus 36:17-20, the texts of Vaticanus and Alexandrinus as well as the textcritical editions of Wevers (1991) and Rahlfs and Hanhart (2006) have the same patterns of coordination, with a uniform pattern of multiple coordination in all rows as opposed to the uniform pattern of final coordination in MT-Exodus 39:10-14. In LXX-Ezekiel 28:13, as indicated by Ziegler (2006) and Rahlfs and Hanhart (2006), the translator(s) use(s) multiple coordination throughout without any indication of rows, as opposed to MT-Ezekiel 28:13, in which rows are implied through the presence of waw in a pattern of final coordination for each row. The pattern of coordination in LXX-Ezekiel 28:13 thus clearly shows that the translator(s) view(s) the stones as simply a list and not as occurring in rows.

\section{The Vulgate lists}

The Vulgate is a fascinating translation in that there is evidence that the translators consulted both the Hebrew and the Greek (see Table 9). ${ }^{11}$ The terms for the stones are identical in the two Exodus lists with one minor exception: V-Exodus

10.Gurtner (2013) does not discuss the coordination patterns exhibited in Vaticanus in Exodus 28:17-20 or 36:17-20, nor do Le Boulluec and Sandevoir (2004) conside patterns of coordination in these passages.

11.The text edition used for the Vulgate is Weber and Gryson (2007).
28:17 has lapis sardius, whereas V-Exodus 39:10 has simply sardius. Almost all of the Latin terms betray Greek influence:

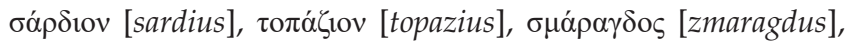

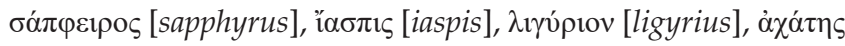

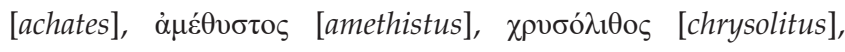

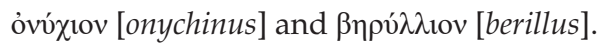

The stones in the two Exodus lists in the Vulgate are in identical order; they follow the LXX except in the reversal of berillus and onycinus. This reversal means that the Vulgate onychinus correlates correctly with the Hebrew שההם [onyx]. However, the Vulgate correlation of iaspis with the LXX' $1 \alpha \sigma \pi 1 s$ should not be correlated with the Hebrew Furthermore, the Vulgate berillus should not be correlated

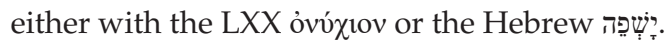

The V-Exodus translator(s) do(es) not harmonise the coordination patterns in the two Exodus lists in contrast to the LXX-Exodus translator(s) and (as will be shown below) the translators of the Syriac, Targum Onqelos and Targum Neofiti. Instead, he uses a unique pattern of coordination both in V-Exodus 28:17-20 (which is closest to, but not identical to, the MT in that most rows have final coordination) and in V-Exodus 39:10-14 in having no coordination at all.

In contrast to the translator(s) of V-Exodus, the translator(s) of V-Ezekiel followed the Hebrew of Ezekiel in translating only nine stones (not 12 as in LXX-Ezekiel). Furthermore, the translator(s) of V-Ezekiel used both final coordination (row 1) and multiple coordination (rows 2 and 3) in contrast to the LXX-Ezekiel pattern of multiple coordination throughout, thus indicating that the V-Ezekiel translator(s) see(s) the stones arranged in rows, as does the MT-Ezekiel (see Table 9). The translator(s) of V-Exodus then used the Vulgate equivalences to the Hebrew stones as indicated in V-Exodus (which are themselves based on the LXX) with the minor exception of onyx in V-Ezekiel 28:13 and onychinus in V-Exodus lists. As a result, the lists of precious stones in V-Ezekiel and LXX-Ezekiel correlate only with respect to the first two stones. 
TABLE 9: Vulgate lists compared to the MT and LXX.

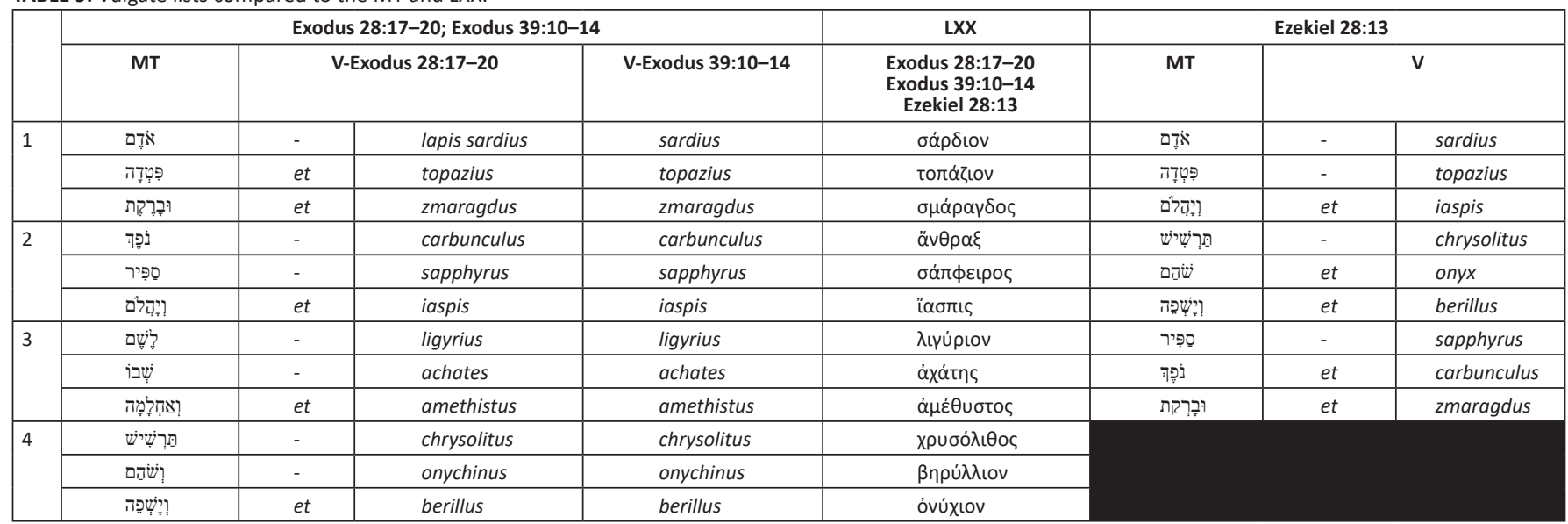

MT, Masoretic Text; V, Vulgate; LXX, Septuagint.

TABLE 10: Syriac lists in Exodus 28 and 39 and Ezekiel 28.

\begin{tabular}{|c|c|c|c|c|c|c|c|c|}
\hline \multirow{4}{*}{1} & \multirow{2}{*}{$\begin{array}{l}\text { MT-Exodus 28:17-20 } \\
\text { MT-Exodus 39:10-14 } \\
\text { DTֶर } \\
\end{array}$} & \multirow{2}{*}{ 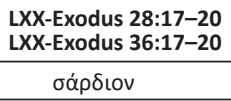 } & \multicolumn{2}{|c|}{$\begin{array}{l}\text { S-Exodus 28:17-20 } \\
\text { S-Exodus 39:10-14 }\end{array}$} & \multirow{2}{*}{ 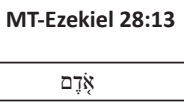 } & \multirow{2}{*}{ 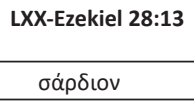 } & \multicolumn{2}{|c|}{ S-Ezekiel 28:13 } \\
\hline & & & $s w m q^{\prime}$ & - & & & srdwn & - \\
\hline & 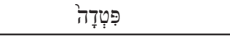 & тота́র̧ıov & wzrg' & waw & פִּטְדָה & тота́ব̆ov & wqrkdn' & waw \\
\hline & וּבדרָּקֶת & $\sigma \mu \alpha \dot{\rho} \alpha \gamma \delta \delta$ & $w b r q^{\prime}$ & waw & וְיְהללם & 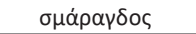 & w'zmrgd' & waw \\
\hline \multirow[t]{3}{*}{2} & נצפקֶר & 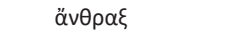 & șdyd' & - & 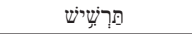 & 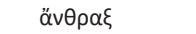 & $w b r w l^{\prime}$ & waw \\
\hline & סַפְִּיר & 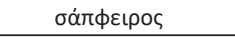 & wspyl' & waw & שֶׁהּם & 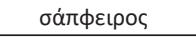 & wspyl' & waw \\
\hline & וחיָהלדם & 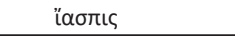 & $w n q ' t^{\prime}$ & waw & 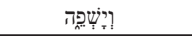 & 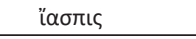 & wyšpwn & waw \\
\hline \multirow[t]{3}{*}{3} & לֶשֶם & $\lambda$ ıүúpıov & qnkynwn & - & סַפְּיר & $\lambda$ tyúpıov & wqrwsțlws & waw \\
\hline & שֶׁבֶּוֹ & 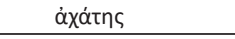 & wqrkdn' & waw & נָפְּד & áxótns & wmrgnyt' & waw \\
\hline & 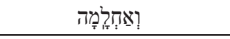 & $\dot{\alpha} \mu \varepsilon \dot{\theta} \theta$ & w'yn 'gl' & waw & וּבְרְתחת & $\dot{\alpha} \mu \varepsilon \dot{\theta} \theta \sigma \tau о \varsigma$ & & \\
\hline \multirow[t]{3}{*}{4} & תמרְּשׁיש & 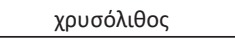 & tršyš & - & & 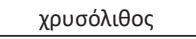 & & \\
\hline & إֹשׁنהם & $\beta \eta \rho u ́ \lambda \lambda ı$ เov & $w b r w l^{\prime}$ & waw & & $\beta \eta \rho u ́ \lambda \lambda ı$ เov & & \\
\hline & 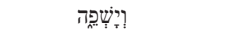 & óvúxıov & wyšph & waw & & óvúxıov & & \\
\hline
\end{tabular}

MT, Masoretic Text; LXX, Septuagint; S, Syriac.

\section{The Syriac lists}

The Syriac translator(s) of Exodus clearly normalised the two lists of precious stones in S-Exodus 28:17-20 and 39:10-14 because the coordination patterns (which differ between the two passages both in the MT and in the LXX) are identical. ${ }^{12}$ The Syriac translator(s) of Exodus follow(s) precisely the pattern of LXX-Exodus 36:17-20 in both Exodus lists. In Ezekiel, the Syriac translator(s) similarly follows the LXX translator(s) in the coordination patterns.

With respect to the rendering of the stones, however, the Syriac translators of Exodus and Ezekiel do not render the stones identically in every case. In the Exodus lists, the Syriac translator(s) uses a term that is cognate to the Hebrew term in the following cases: $b r q^{\prime}$, spyl', tršyš and yšph (see Table 10).

The first stone, swmq', is derived from the adjective 'red'; the term is also used for other red items (e.g. red lentils, red pottage, red or purple dye, rouge) (Payne Smith 1903:367; Sokoloff 2009:981-982). It is therefore an appropriate rendering of the Hebrew (sardius)' (Sokoloff 2009:981-982).

12.The Leiden Peshitta is used as the text edition for the Syriac texts, namely, Ter Haar Rominey and Van Peursen (2016) and Mulder (1993).
The second stone, $z r g^{\prime}$ ', is again based upon an adjective, meaning 'shining' or 'reddish' (Sokoloff 2009:396-397). Payne Smith describes it as a 'wine colour, a colour between yellow and red, a topaz, amethyst' (Payne Smith 1903:120).

The third stone, brq', is related to the Hebrew בָרָק and means 'emerald' (Payne Smith 1903:56; Sokoloff 2009:192).

The fourth stone, șdyd', is derived from Akkadian șadidu, meaning 'antimony, stibium' (Sokoloff 2009:1274). Payne Smith defines it as 'a. the carbuncle, b. antimony, black lead, paint for the eyes' (Payne Smith 1903:474).

The fifth stone, wspyl', is related to the Hebrew ợ and

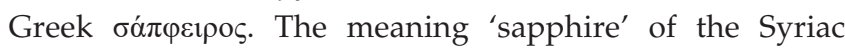
lexicographers (Payne Smith 1903:385; Sokoloff 2009:1030) seems to be based on the later referent of the Hebrew and Greek terms because the only texts listed by the lexicographers are these Exodus lists. The Hebrew, Greek and Syriac terms rather refer to lapus lazuli, a soft dark blue stone used throughout the ancient Near East. The sapphire was unknown until much later because it is too hard to be cut with ancient techniques (see Naudé \& Miller-Naudé 2020). 
TABLE 11: Comparison of Targum lists to MT and LXX lists in Exodus.

\begin{tabular}{|c|c|c|c|c|c|c|}
\hline & MT & LXX in MT order & Onqelos & Pseudo-Jonathan & Neofiti & LXX order \\
\hline \multirow[t]{3}{*}{1} & אָָדָד & 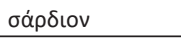 & סָמְקָוֹן & סמוקתא & סמקתה & 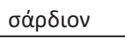 \\
\hline & פִּטְדָדה & 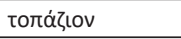 & ירוקוּו & ירקתא & וירקתה & тола́łı๐ov \\
\hline & וּרָרְקָת & $\sigma \mu \alpha \dot{\alpha} \alpha \gamma \delta$ os & וּרָרְקוּו & וברקתא & וברקתה & $\sigma \mu \alpha ́ \rho \alpha \gamma \delta о \varsigma$ \\
\hline \multirow[t]{3}{*}{2} & 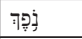 & $\alpha \ddot{v} \theta \rho \alpha \xi$ & 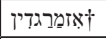 & איזמורד & כדכדינה & $\alpha \ddot{v} \theta \rho \alpha \xi$ \\
\hline & סַפְּיר & 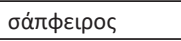 & שטבבזיזי & וספירינון & tלוספרינה & 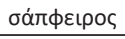 \\
\hline & ויניהדלם & $\beta \eta \rho u ́ \lambda \lambda ı$ เov & 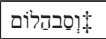 & וכדכודין & ועין־עגלה & 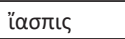 \\
\hline \multirow[t]{3}{*}{3} & לקשֶׁם & $\lambda$ ¿үúpıov & 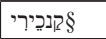 & קנכירינון & לשם זוזין & $\lambda$ Aıúpiov \\
\hline & שִֶׁבוֹ & 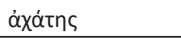 & 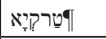 & וטרקין & וברולין & áxátns \\
\hline & וֹאִחְלָָׁה & $\dot{\alpha} \mu \varepsilon \dot{\theta} \theta$ & 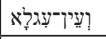 & ועין עיגל & וזמרגדיון & $\dot{\alpha} \mu \varepsilon \dot{\theta} \theta$ טто \\
\hline \multirow[t]{3}{*}{4} & תמּרְשׁׁיש & 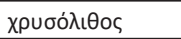 & כְרֵום יָמָא & כרום ימא רבא & כרום (ו)]י[מה & 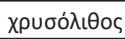 \\
\hline & וֹושיָהם & óvúxıov & וְבְורלְא & ובירליוות חלא & ובדלחא & $\beta \eta \rho u ́ \lambda \lambda ı$ เov \\
\hline & 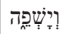 & ı̋ $\alpha \sigma \pi \iota \varsigma$ & 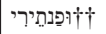 & ומרגניית אפנטורין & ומרגליתה | & óvúxเov \\
\hline
\end{tabular}

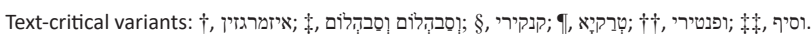

MT, Masoretic Text; LXX, Septuagint.

The sixth stone, $n q$ ' $t$ ', is not identified precisely by the Syriac lexicographers. Sokoloff defines it as 'gem, perhaps topaz' and suggests that the term may be derived by metathesis from ענקתא [necklace] (Sokoloff 2009:947). Payne Smith defines it only as a dark-coloured or honey-coloured gem (Payne Smith 1903:351).

The seventh stone, qnkynwn, is explained by the Syriac lexicographers as a 'somewhat yellow gem' (Sokoloff 2009:1385) and as 'a gem, reddish amber, jacinth' (Payne Smith 1903:511).

The eighth stone, $q r k d n^{\prime}$, is clearly derived from Greek

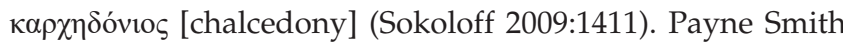
provides the meaning 'chalcedony, carnelian' (Payne Smith 1903:519).

The ninth stone, $w$ 'yn ' $g l$ ', literally 'calf's eye', is a metaphorical description of a precious stone. Payne Smith describes it generally as 'some precious stone, perhaps sardonyx or amethyst' (Payne Smith 1903:411). Sokoloff identifies it as 'crowndaisy (Chrysanthemum coronarium)' (Sokoloff 2009:1097).

The 10th stone, tršyš, is from the Hebrew הִִּ It is identified as 'chrysolite (Gemma alba)' (Sokoloff 2009:1673) and 'chrysolith' (Payne Smith 1903:622).

The 11th stone, brwl', is identified by Sokoloff (2009:187) as 'beryl' and derived from Parthian bylwr (similarly, Payne Smith 1903:55).

The 12th stone, yšph, is clearly identified as 'jasper' (Payne Smith 1903:198; Sokoloff 2009:586). Sokoloff notes its derivation from Akkadian yašpu (Sokoloff 2009:586).

The Syriac translator(s) of Ezekiel uses the following stones that are not found in the Exodus lists: srdwn [sardion]

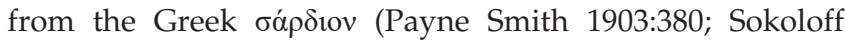
2009:1043); 'zmrgd' from the Greek $\sigma \mu \alpha \rho \alpha \gamma \delta$ os (Payne Smith 1903:9; Sokoloff 2009:25); yšpwn, an alternate form of 'jasper' (Payne Smith 1903:14; Sokoloff 2009:37); qrwstliws,

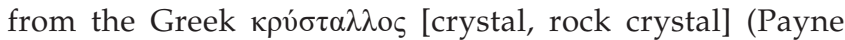

Smith 1903:518; Sokoloff 2009:1405); mrgnyt' from the

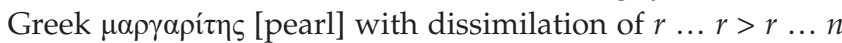
(Payne Smith 1903:299; Sokoloff 2009:826).

\section{The Targum lists}

Targum Onqelos has the same stones in the same order in the Exodus 28 and 39 lists. The same is true of Targum Pseudo-Jonathan and Targum Neofiti. However, the three targumim do not agree with respect to either the stones or their order. ${ }^{13}$ Onqelos and Pseudo-Jonathan are closest, but not identical (Table 11).

Pseudo-Jonathan and Neofiti explicitate the names of the tribes in the Exodus lists, but they differ in the order in which they list the sons (Table 12). Pseudo-Jonathan explicitates the names of the tribes using the birth order of the sons. Neofiti explicitates the names of the tribes based upon the mothers - Leah's sons, then Rachel's sons, then the sons of Bilha (Rachel's maid) and the sons of Zilpah (Leah's maid) as specified in Genesis 35:22-26. A comparison of the two lists demonstrates that there is no symbolic relationship between a specific stone and one of the sons; instead, different traditions concerning the listing of the sons drawn from the biblical text were applied to two different lists of stones.

A comparison of the coordination patterns (Table 13) shows clearly that Onqelos normalises to the Hebrew of Exodus 28:17-20, whereas Neofiti normalises to LXX-Exodus 36. Pseudo-Jonathan follows manuscripts such as Vaticanus in LXX-Exodus 28:17-20 (see Table 8), as well as the Hebrew of Exodus 28:17-20 in the first row, and then continues with the pattern of LXX-Exodus 36 for the remaining rows. Further examples of the ways in which the translator(s) of PseudoJonathan attempt(s) to incorporate the readings of both Onqelos and Neofiti in his (their) translation are indicated below.

The order of the stones in Neofiti differs with respect to the other two targumim with respect to the location of three 13.The text editions for the targumim include Clarke (1984), Cohen (1992), the Comprehensive Aramaic Lexicon Project, Levy (1986) and Sperber (1992a, 1992b). 
TABLE 12: Targumim of Exodus 28 and 39 with explicitation of tribal names.

\begin{tabular}{|c|c|c|c|c|c|c|}
\hline \multirow[b]{2}{*}{1} & \multirow{2}{*}{$\begin{array}{l}\text { MT } \\
\text { MTֶ }\end{array}$} & \multirow{2}{*}{$\begin{array}{l}\text { Onqelos } \\
\text { סָמְּקָ }\end{array}$} & \multicolumn{2}{|c|}{ Pseudo-Jonathan } & \multicolumn{2}{|c|}{ Neofiti } \\
\hline & & & סמוקתא & Reuben & סמקתה & Reuben \\
\hline & טְְִּדָדה & זָרְקָן & ירקתא & Simeon & וירקתה & Simeon \\
\hline & וּבדרָרְקת & וּבְרָקָּו & וברקתא & Levi & וברקתה & Levi \\
\hline \multirow[t]{3}{*}{2} & נצפֶֶר & 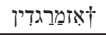 & איזמורד & Judah & כדכדינה & Judah \\
\hline & סַפְִּיר & שלַבזּיז & וספירינון & Dan & 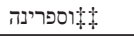 & Issachar \\
\hline & ויוְהלדם & 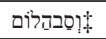 & וכדכודין & Naphtali & ועין־עגלה & Zebulon \\
\hline \multirow[t]{3}{*}{3} & לֶשֶם & א§נכֵירי & קנכירינון & Gad & לשם זוזין & Dan \\
\hline & שָׁבְרוֹ & 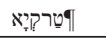 & וטרקין & Asher & וברולין & Naphtali \\
\hline & 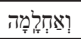 & וועיו־עיעגלדא & ועין עיגל & Issachar & וזמרגדין & Gad \\
\hline \multirow[t]{3}{*}{4} & תמרְשׁׁיש & כְרֵום יְְמָא & כרום ימא רבא & Zebulon & כרום (ו)]']מה & Asher \\
\hline & 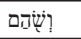 & וְבְורלְא & ובירליוות חלא & Joseph & ובדלחא & Joseph \\
\hline & 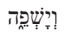 & 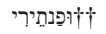 & ומרגניית אפנטורין & Benjamin & ומרגליתה & Benjamin \\
\hline
\end{tabular}

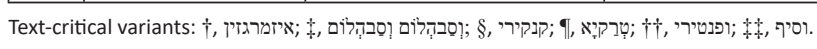

MT, Masoretic Text.

TABLE 13: Targum coordination patterns in Exodus lists.

\begin{tabular}{|c|c|c|c|c|c|c|c|c|c|c|}
\hline & \multicolumn{2}{|c|}{ MT-Exodus 28} & \multicolumn{2}{|c|}{ Onqelos } & \multicolumn{2}{|c|}{ Pseudo-Jonathan } & \multicolumn{2}{|c|}{ Neofiti } & \multirow{2}{*}{$\begin{array}{c}\text { LXX-Exodus } 28 \text { (B) } \\
-\end{array}$} & \multirow{2}{*}{$\begin{array}{c}\text { LXX-Exodus } 36 \\
-\end{array}$} \\
\hline \multirow[t]{3}{*}{1} & אָדֶדם & - & סָמָקוּן & - & סמוקתא & - & סמקתה & - & & \\
\hline & פְְִּדָה & - & צירְקָן & - & ירקתא & - & וירקתה & waw & - & $k a i$ \\
\hline & וּבְרָקְת & waw & וּרָרְֶָו & waw & וברקתא & waw & וברקתה & waw & kai & kai \\
\hline \multirow[t]{3}{*}{2} & נֶֶֶֶר & - & 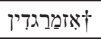 & - & איזמורד & - & כדכדינה & - & - & - \\
\hline & סֵפְּיר & - & שַַבזָיז & - & וספירינון & waw & 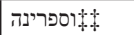 & waw & kai & kai \\
\hline & ויוּהלדם & Waw & 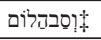 & waw & וכדכודין & waw & ועין־עגלה & waw & kai & kai \\
\hline \multirow{2}{*}{3} & שָׁבְוֹ & - & | & - & וטרקין & waw & וברולין & waw & - & $k a i$ \\
\hline & וֹאַחְלָלָה & waw & וְעַין־עַגלִא & waw & ועין עיגל & waw & וזמרגדין & waw & kai & $k a i$ \\
\hline \multirow[t]{3}{*}{4} & תַּרְשׁׁיש & - & כְרְום יַמָא & - & כרום ימא רבא & - & כרום (ו)]י[מה & - & - & - \\
\hline & 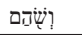 & waw & וְבְורלְא & waw & ובירליוות חלא & waw & ובדלחא & waw & kai & kai \\
\hline & 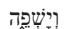 & waw & 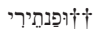 & waw & ומרגניית אפנטורין & waw & ומרגליתה & waw & kai & kai \\
\hline
\end{tabular}

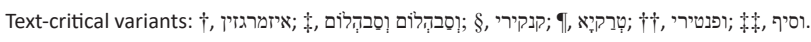

MT, Masoretic Text; LXX, Septuagint.

stones (see Table 14). The stone כדכודין, which is in final position in row 2 in Onqelos and Pseudo-Jonathan, is in the first position of row 2 in Neofiti. The stone איזמורד, which is in first position in row 2 in Onqelos and PseudoJonathan, is in final position in row 3 in Neofiti. The stone עין עיגל, which is in final position in row 3 in Onqelos and Pseudo-Jonathan, is in final position in row 2 in Neofiti. In effect, the Neofiti translator(s) has moved three stones that are on the margins of the middle two rows in a clockwise rotation.

The first three stones in all three targumic lists in Exodus are identical or very close variants (Table 15). Thereafter, Onqelos and Pseudo-Jonathan show the greatest similarity with respect to the names of the stones and their order. They differ with respect to their rendering of four stones - the last two stones in row 2 and the last two stones in row 4 . In row 2, the

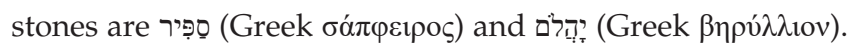
In row 4, Pseudo-Jonathan incorporates the rendering of

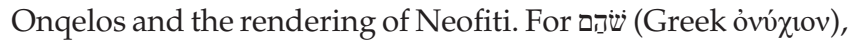

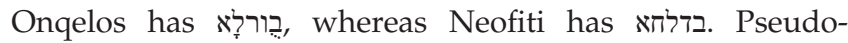
Jonathan combines the renderings to read בירליוות חלא.

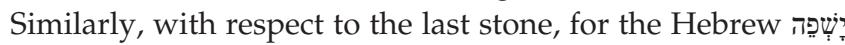

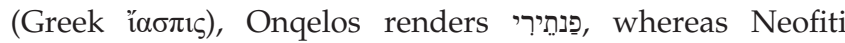
renders מרגליתה; Pseudo-Jonathan combines the two to read מרגניית אפנטורין A detailed examination of each term used in the targumim follows.
Each of the terms used in the targumim for the first stone (Hebrew אị) relates to the basic meaning 'red'. The translation in Onqelos is סָמְזָ , the masculine noun meaning 'red jewel, carnelion' (Jastrow 1967:1003), Targum PseudoJonathan's סמוקתא is a determined feminine noun, meaning 'red jewel' (Sokoloff 2002:381) related to the adjective [red] (Sokoloff 2002:381). The translation of the Targum Neofiti סמקתה is the determined form of the feminine noun סמק [red stone] (Sokoloff 2002:383) from the verb red] (Sokoloff 2002:383). Each of the targumim thus focuses on translating the colour of the stone.

Each of the Targum terms for the second stone (Hebrew פד? also refers to the colour of the stone without identifying it; the colour is greenish (Jastrow 1967:598; Sokoloff 2002:246). This translation strategy indicates that the translators of the targumim were not sure what the stone is; it is not clear how they deduced that the colour is green.

The third stone (Hebrew ברְְָר) is translated by the targumim with two alternate forms of the Hebrew as a loanword into Aramaic - Oneqelos uses ברָזָז whereas Pseudo-Jonathan and Neofiti use alternate spellings of the singular determined noun ברקה. These nouns are not known from other Aramaic literature, and thus the identification of the jewel is uncertain (Sokoloff 2002:115); Jastrow (1967:197) suggests that it is probably smaragd (from the LXX rendering $\left.\sigma \mu \alpha \dot{\alpha} \rho \alpha \gamma \delta \delta_{)}\right)$. 
The fourth stone (Hebrew נפקֶּ is translated by Onqelos and Pseudo-Jonathan with two variants of a loan item from the Greek $\sigma \mu \alpha \dot{\alpha} \rho \alpha \gamma \delta$ איזמורז respectively, which are identified as 'emerald, a jewel (or colored crystal)' (Jastrow 1967:38). Neofiti uses a completely

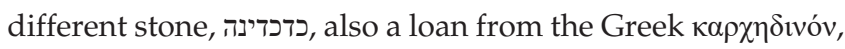
which means 'chalcedony' (Sokoloff 2002:251).

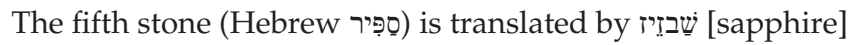
(Jastrow 1967:1511) and by the alternate terms ספירינון and ספרינה [sapphire] (Sokoloff 2002:385-386]) in Pseudo-Jonathan and Neofiti, respectively.

In sixth position, the targumim have three different terms.

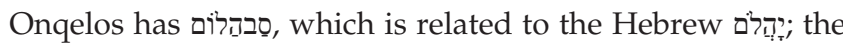
term is otherwise unknown, according to Jastrow (1967:949). Pseudo-Jonathan has כדכודין, one of the alternate terms for 'chalcedony' (see Sokoloff 2002:251). Neofiti has עין-עגלה, literally 'calf's eye', a metaphorical term for a precious stone (Sokoloff 2002:403).

In seventh position, the targumim have three different terms. Onqelos has wנכיריר, which Jastrow (1967:1393) identifies as corresponding to $\kappa \varepsilon ́ \gamma \chi \rho \eta ~(=\kappa \varepsilon ́ \gamma \chi \rho \circ \varsigma)$ and referring to 'a small kind of diamond'. Pseudo-Jonathan renders it with an alternate form of the same term, קנכירינון. Neofiti renders it with לשם זוזין, combining a reflex of the Hebrew לֶשֶם (Sokoloff 2002:287) with the generic plural זוזין [jewels] (Sokoloff 2002:174).

In eighth position, Onqelos and Pseudo-Jonathan have

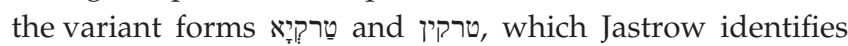

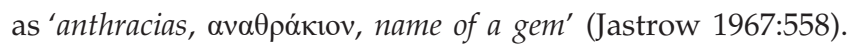
Neofiti translates it with ברולין [beryll] from the Greek $\beta \eta ́ \rho v \lambda \lambda$ os (Sokoloff 2002:102).

TABLE 14: Neofiti rotation of three stones.

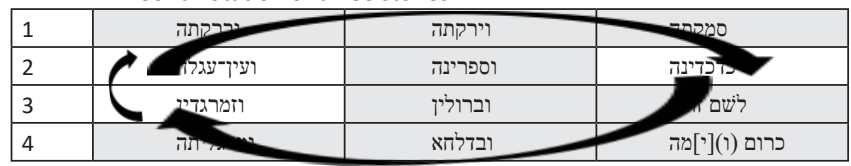

Note: Grey shading indicates the stones that correspond across the lists.
In ninth position, Onqelos and Pseudo-Jonathan have the

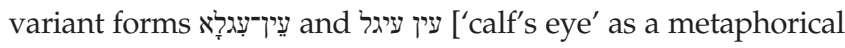
name of a gem] (Sokoloff 2002:403). Neofiti has זמרגדין, a loanword from the Greek $\sigma \mu \alpha \dot{\rho} \alpha \gamma \delta$ os [emerald] (Sokoloff 2002:179).

In 10th position, the targumim have variants of the same

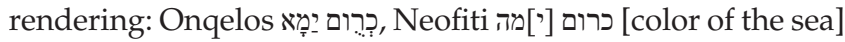
and Pseudo-Jonathan כרום ימא רבא [color of the great sea]. The word כרום is a loanword from the Greek $\chi \rho \tilde{\omega} \mu \alpha$ [color]; the phrase describes sea green as a description of a jewel (Jastrow 1967:665; Sokoloff 2002:268).

In 11th position, Onqelos has רֶורלְ, a loanword from the

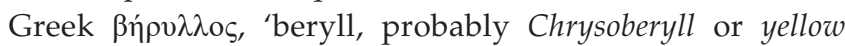
emerald' (Jastrow 1967:166). Neofiti has בדלחא [a precious stone] (Sokoloff 2002:85). Pseudo-Jonathan seems to combine the two renderings to produce ובירליוות חלא.

In 12th position, Onqelos has פַניתיריר, a term derived from the Greek $\pi \alpha ́ v \theta \eta \rho$ [panther] and indicating a spotted stone (Jastrow 1967:1191). Neofiti has מרגליתה, a term derived from the Greek $\mu \alpha \rho \gamma \varepsilon \dot{\lambda} \lambda$ iov [pearl] (Sokoloff 2002:327-328). Pseudo-Jonathan again combines the renderings of Neofiti and Onqelos with the rendering מרגניית אפנטורין

It is clear that the translators of the targumim often do not know how to identify the stones of their Vorlage, and often they do not have an equivalent technical term for rendering them into Aramaic. As a result, they often resort to using colour terms or descriptive terms in addition to loanwords for their renderings. Furthermore, it is clear that the Ezekiel translators of the targumim worked independently without reference to the translations of Exodus.

\section{The lists in Josephus}

Josephus describes the stones in the breastpiece of the high priest in two of his writings. In The Wars of the Jews (Wars) (Book 5, Chapter 5, Section 7), Josephus provides one list of the stones. In The Antiquities of the Jerws (Antiquities) (Book 3, Chapter 7, Section 5), he updates his list, presumably to

TABLE 15: Similarities amongst terms for precious stones in Targum lists.

\begin{tabular}{|c|c|c|c|c|}
\hline & Onqelos & Pseudo-Jonathan & Neofiti & Comments \\
\hline 1.1 & סָמָזָן & סמוקתא & 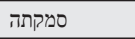 & Identical stones (slight variations in lexical forms) \\
\hline 1.2 & דירוקו & ירקתא - (ירא & וירקתה & Identical stones (slight variations in lexical forms) \\
\hline 1.3 & וּרָרְקוּן & וברקתא & וברקתה & Identical stones (slight variations in lexical forms) \\
\hline 2.1 & אָזמברגדין & איזמורד & כדכדינה & $\mathrm{O}=\mathrm{PS} ; \mathrm{N}=\mathrm{PJ}$ in 2.3 \\
\hline 2.2 & 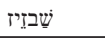 & וספירינון & וספרינה & $P S=N$ \\
\hline 2.3 & 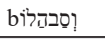 & 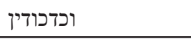 & ועין־עגלה & $\mathrm{PJ}=\mathrm{N}$ in $2.1 ; \mathrm{N}=\mathrm{O}, \mathrm{PJ}$ in 3.3 \\
\hline 3.2 & טַרקְיָא & וטרקין & וברולין - ובין & $\mathrm{O}=\mathrm{PJ} ; \mathrm{N}=\mathrm{O}, \mathrm{PJ}$ in 4.2 \\
\hline 3.3 & וֹעיו־עִגלרא & ועין עיגל & 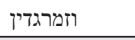 & $\mathrm{O}=\mathrm{PJ} ; \mathrm{N}=\mathrm{O}, \mathrm{PJ}$ in 2.1 \\
\hline 4.1 & כְרֶום יְיָא & כרום ימא רבא & כרום (1)]']מה & Identical stones (slight variations in lexical forms) \\
\hline 4.2 & (ְבְורלְץא & 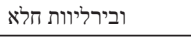 & 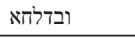 & $\mathrm{O}=\mathrm{PJ} ; \mathrm{N}=\mathrm{PJ}(\mathrm{PJ}$ combines $\mathrm{O}$ and $\mathrm{N})$ \\
\hline 4.3 & 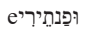 & ומרגניית אפנטורין & ומרגליתה & $\mathrm{O}=\mathrm{PJ} ; \mathrm{N}=\mathrm{PJ}(\mathrm{PJ}$ combines $\mathrm{O}$ and $\mathrm{N})$ \\
\hline
\end{tabular}

Note: Grey shading indicates the stones that correspond across the lists.

O, Onqelos; PJ, Pseudo-Jonathan; N, Neofiti. 
correct it. Table 16 presents the two lists of Josephus and compares them to the LXX.

The three lists are quite similar, in spite of many minor differences. Six terms in the LXX find their precise counterparts in the same order in Josephus - four in Wars, three in Antiquities. The first row most closely reflects the LXX, with one major exception and one minor exception.

The major exception involves $\sigma \alpha \rho \delta$ óvv $\xi$ in Antiquities; the

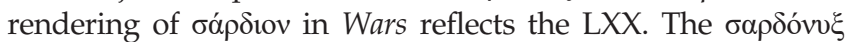
[sardonyx] is a type of onyx that is red or brown with white stripes; it is therefore an appropriate rendering for the Hebrew פֶדא on the basis of its reddish colour. The term $\sigma \alpha \rho \delta$ óvv $\xi$ is known only from Roman times; before Roman times, the term óv' $\xi$ and its variant óvóxiov could be used for onyx that was black, brown or red (Naudé \& Miller-Naudé 2020). The

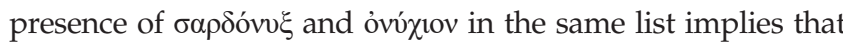
óvó $10 v$ has a narrowed definition and refers only to black onyx.

The minor exception occurs in the second row, where the

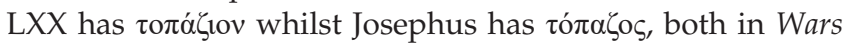
and Antiquities. Liddell and Scott view the two forms as alternative forms of the noun (1978:1805).

In the second row, all of the terms in Antiquities are in the accusative case because of the sentence in which they occur.
The other two stones are in reverse order in the LXX and

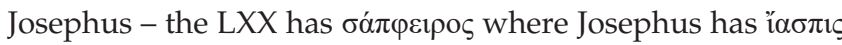
or i $\alpha \sigma \pi \mathrm{v}$ (the former is the nominative, the latter is the

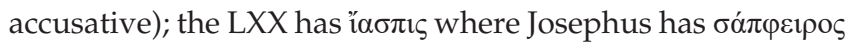
(or the accusative бó $\pi \varphi \varepsilon i \rho o v)$.

In the third row, Josephus places $\dot{\alpha} \mu \varepsilon \dot{\theta} \theta v \sigma \tau o \varsigma$ as the center stone, where the LXX has áx'́) $\dot{\alpha} \mu \varepsilon \dot{\theta} \theta \sigma \tau \tau \varsigma$ and $\lambda$ ivóptov after in War, with the reverse order of the two stones in Antiquities. As a result, the only stone corresponding to the LXX is the first stone, where Antiquities has $\lambda$ íropos corresponding to the LXX $\lambda$ irópıov. In the fourth row, the LXX has the order $\chi \rho v \sigma o ́ \lambda \imath \theta_{0} \varsigma, \beta \eta \rho v ́ \lambda \lambda_{10 v}$, ovvó $\chi 10 v$. Josephus reflects two other orders of the two stones. The first

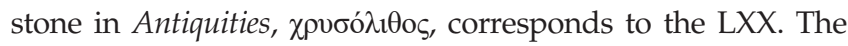

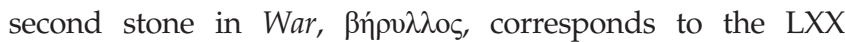
$\beta \eta \rho v ́ \lambda \lambda 10 v$, the diminutive form of $\beta \eta \dot{\rho} \rho \nu \lambda \lambda_{\circ}$ (Liddell \& Scott

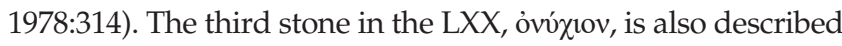
by Liddell and Scott $(1978: 1234)$ as the dimunitive form of övv

The most striking feature of the lists in Josephus is the alternate order of stones within the rows. In row 2, the alternate order involves two adjacent stones. In row 3, the alternate order involves which stone is in the middle of the row. In row 4 , the alternate order involves $\chi \rho v \sigma o ́ \lambda 1 \theta o s$ at the beginning or end of the row (Table 17).

TABLE 16: Precious stones of the breastpiece in Josephus' The Wars of the Jews and The Antiquities of the Jews compared to the Septuagint.

\begin{tabular}{|c|c|c|c|c|}
\hline & Wars & Antiquities & LXX & Notes \\
\hline \multirow[t]{3}{*}{ Row 1} & 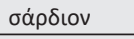 & $\sigma \alpha \rho \delta o ́ v u \xi$ & 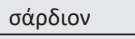 & $\mathrm{W}(=\mathrm{LXX}) ; \neq \mathrm{A}$ (different stone) \\
\hline & 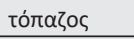 & то́лаگоৎ & тота́łı̀v & $\mathrm{W}=\mathrm{A} \approx \mathrm{LXX}$ (morphological variation) \\
\hline & 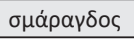 & 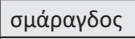 & 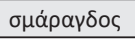 & $W=A=L X X$ \\
\hline \multirow[t]{3}{*}{ Row 2} & 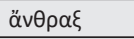 & ävӨрак $\alpha$ & 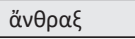 & Row 2, stone 1: $\mathrm{W}=\mathrm{A}=\mathrm{LXX}$ \\
\hline & 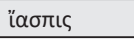 & i $\alpha \sigma \pi ı$ & 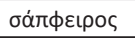 & 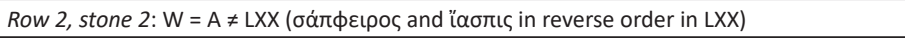 \\
\hline & 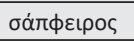 & 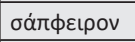 & iaorıs & 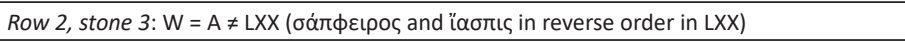 \\
\hline \multirow[t]{3}{*}{ Row 3} & áxátns & $\lambda$ ípupos & $\lambda$ ipúpıov & 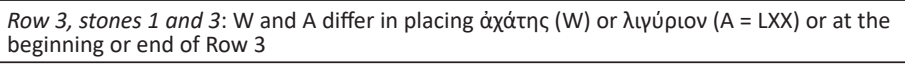 \\
\hline & $\dot{\alpha} \mu \dot{\theta} \theta$ & 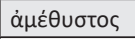 & 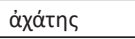 & \multirow{2}{*}{ 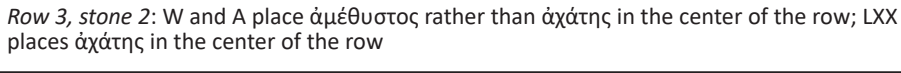 } \\
\hline & $\lambda$ ¿ıúpıov & 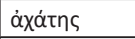 & $\dot{\alpha} \mu \dot{\theta} \theta$ & \\
\hline \multirow[t]{3}{*}{ Row 4} & övu६ & 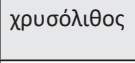 & 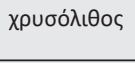 & 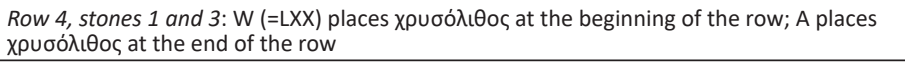 \\
\hline & 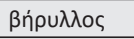 & övu६ & $\beta \eta \rho u ́ \lambda \lambda ı$ เov & 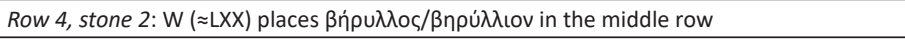 \\
\hline & 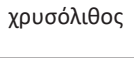 & 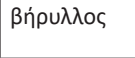 & óvúxtov & $\begin{array}{l}\text { Row 4, stone } 3 \text { : As a result of the changes in this row amongst the three texts, this stone is } \\
\text { different in the three texts. }\end{array}$ \\
\hline
\end{tabular}

Note: Grey shading indicates identical stones (indicated by $=$ in the notes) or stones that differ only with minor morphological variations (indicated by $\approx$ in the notes).

LXX, Septuagint; W, The Wars of the Jews; A, The Antiquities of the Jews.

TABLE 17: Summary of changes made in The Antiquities of the Jews as compared to The Wars of the Jews.

\begin{tabular}{|c|c|c|c|}
\hline & Wars & Antiquities & Notes \\
\hline \multirow[t]{3}{*}{ Row 1} & 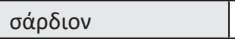 & $\sigma \alpha \rho \delta$ óvu६ & Antiquities substitutes a different stone. \\
\hline & то́лаگоৎ & то́таろоక & - \\
\hline & 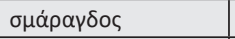 & 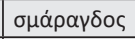 & - \\
\hline \multirow[t]{3}{*}{ Row 2} & 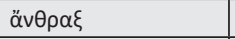 & 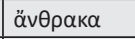 & In Antiquities, the stones of the second row are in the accusative case because they serve as the object of the sentence. \\
\hline & 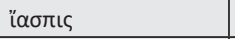 & 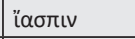 & - \\
\hline & 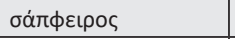 & 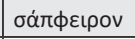 & - \\
\hline \multirow{2}{*}{ Row 3} & $\dot{\alpha} \mu \varepsilon \dot{\theta} \cot >$ & 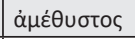 & - \\
\hline & גıүúpiov & áxótns & Antiquities moves áxátnৎ to the end of the row and $\lambda$ iүupo to the beginning of the row. \\
\hline \multirow[t]{3}{*}{ Row 4} & övuk & 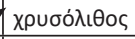 & Antiquities moves $\chi \rho \cup \sigma o ́ \lambda t \theta o \zeta$ from the end of the row to the beginning of the row. \\
\hline & $\beta \dot{\rho} \rho \cup \lambda \lambda \circ \varsigma$ & övu६ & Antiquities moves övu乡 from first position to second position. \\
\hline & 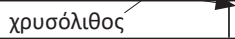 & $\beta \operatorname{\rho } \rho \cup \lambda \lambda$ os & 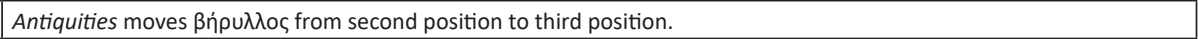 \\
\hline
\end{tabular}

Note: Grey-shaded boxes indicate identical stones in the same order.

Wars, The Wars of the Jews; Antiquities, The Antiquities of the Jews. 
In Antiquities, Josephus rejects the adjectival form $\lambda$ ryv́pıov as found in his Wars and the LXX. He also reverses the order of the first and last stones in the row in Antiquities,

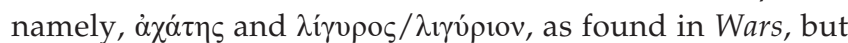
retains $\dot{\alpha} \mu \varepsilon \dot{\varepsilon} \theta v \sigma \tau \varsigma$ as the central stone in the row (contra the LXX). In Antiquities, he also reverses the order of $\chi \rho v \sigma o ́ \lambda \imath \theta o s$ in the row from last position (as found in Wars) to first position (as found in LXX). Antiquities then moves övv $\xi$ and

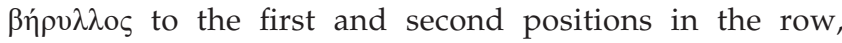
respectively.

The reasons behind Josephus' ordering of the stones and the differences between his two lists are not clear. However, Josephus' explicit descriptions of the vestments of the high priest (Antiquities Book 3, Chapter 7, Section 7) as having colour symbolism and the breastpiece as related to the Greek zodiac are almost certainly relevant. We return to colour symbolism below.

\section{The precious stones in the New Jerusalem (Rv 21:19-20)}

In Revelation 21, the New Jerusalem is described as having 'a great, high wall with 12 gates, and with 12 angels at the gates. On the gates were written the names of the 12 tribes of Israel' (Rv 21:12). ${ }^{14}$ Although the stones are not explicitly arranged in rows, the rows are implied by the fact that the stones are arranged in four groups of three by the phonological ending of the third, sixth and ninth stones in the Greek letter $n u$ (see Table 18). ${ }^{15}$ This arrangement of the phonological shapes of the stones is indexical of the use of a trisyllabic structure of the words in the Hebrew lists in Exodus 28 and 39 (see Table 1). ${ }^{16}$

Table 19 shows the translations of the Vulgate and the Syriac of the stones in this passage. The Vulgate translation of Revelation 21:19-20 is clearly based upon the Greek incipient text. ${ }^{17}$ In the Syriac translation of Revelation 21:19-20, it is clear that some stones are identical to those found either in S-Exodus 28/39 (e.g. yšph), in S-Ezekiel 28:13 (e.g. zmrgd', srdwn) or in both (e.g. spyl', grkdn', brwl'), whilst others are based upon the Greek incipient text (e.g. twopndywn, krwsprs', ywktws, 'mwtss). The Syriac translation of this passage will not be considered further here.

When the stones in New Jerusalem are compared to the LXX translation of the stones in the breastpiece of the high priest (Table 20), there are six stones that are identical, namely,

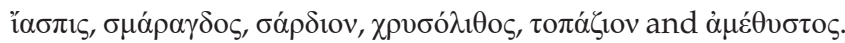

14.The text edition used for the New Testament is Aland et al. (2012).

15.There are many aspects of the precious stones in this passage, their identification, arrangement and relation to the other lists of precious stones, which cannot be considered here. For an in-depth and unique approach to this passage, see Charles (1920, 2:165-170)

16.By 'indexical', we refer to the fact that the author of Revelation 21:19-20 semiotically points to the indication of the ends of rows in the lists of MT-Exodus 28 and 39 , without mimicking their arrangement of bisyllabic and trisyllabic nouns.

17.In accordance with Marais (2019), we use the terms 'incipient text' rather than 'source text' and 'subsequent text' rather than 'target text'.
TABLE 18: Phonological arrangement of the precious stones in Revelation 21:19-20.

\begin{tabular}{|c|c|}
\hline Greek & Phonological ending \\
\hline \multicolumn{2}{|l|}{ ïaorıs } \\
\hline \multicolumn{2}{|l|}{ 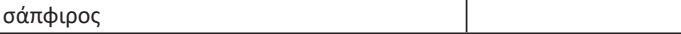 } \\
\hline$\chi \alpha \lambda \kappa \eta \delta \omega \dot{~}$ & $-v$ \\
\hline \multicolumn{2}{|l|}{ 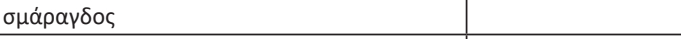 } \\
\hline \multicolumn{2}{|l|}{ 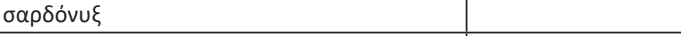 } \\
\hline 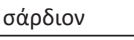 & $-v$ \\
\hline \multicolumn{2}{|l|}{ 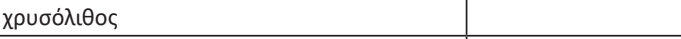 } \\
\hline \multicolumn{2}{|l|}{$\beta \operatorname{\rho ́}$} \\
\hline тота́)̧ıov & $-v$ \\
\hline \multicolumn{2}{|l|}{ хрибо́трабоৎ } \\
\hline \multicolumn{2}{|l|}{ úákıเvo૬ } \\
\hline$\dot{\alpha} \mu \varepsilon \dot{\theta} \theta$ uтоৎ & \\
\hline
\end{tabular}

Two stones are morphological variants of the LXX stones,

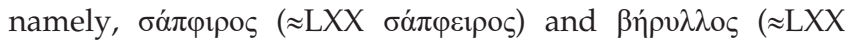
$\beta \eta \rho u ́ \lambda \lambda$ iov).

There are four stones not in the LXX, namely, $\chi \alpha \lambda \kappa \eta \delta \omega$,

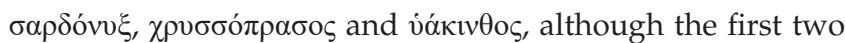
are known from other lists (for argumentation, see Naudé \& Miller-Naudé 2020). The first, chalcedony (Greek $\chi \alpha \lambda \kappa \eta \delta \omega ́ v)$, is used by the Syriac ( $q r k d n$ ') as the translation equivalent of

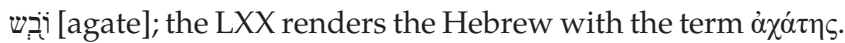
It seems that the writer of Revelation has substituted $\chi \alpha \lambda \kappa \eta \delta \omega$ v, a rendering reflected in Syriac, for the LXX term

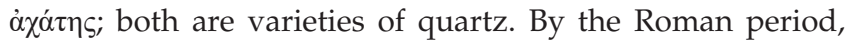
agate had lost its value as a precious stone, and chalcedony was substituted. Chacedony is very similar to agate, except that it is milk white and does not have white bands as does agate.

The second stone, $\sigma \alpha \rho \delta$ óvv $\xi$, is a reddish-brown variety of onyx. It was used as a rendering for the Hebrew אדָ by Josephus in his Antiquities (see Table 16) in place of the LXX

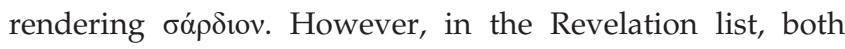

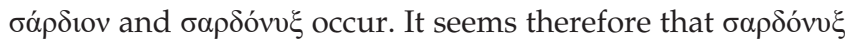
is used in place of óvíquv [onyx]; both are quartz. The $\sigma \alpha \rho \delta$ óvv $\xi$ stone was unknown until Roman times, but became very popular as a precious stone.

The third stone, $\chi \rho v \sigma \sigma o ́ \pi \rho \alpha \sigma o \varsigma$, is very rarely attested, but seems to be the replacement for the difficult LXX term ó $v \theta \rho \alpha \xi$ (see Naudé \& Miller-Naudé 2020).

The fourth stone, vókıv $\theta$ os, is hyacinth. It is a newer term and replaces the LXX term $\lambda$ irúpiov, which is very rare and which was used to translate the Hebrew לֶ?

The precious stones of the foundation of the New Jerusalem with the apostles' names on them are thus a reflection of the precious stones of the breastpiece of the high priest as translated by the LXX. In four instances, stones from the LXX list were replaced when the writer of Revelation substituted fresh equivalents for stones that were rare or unknown. 
TABLE 19: Precious stones in Revelation 21:19-20 and their Latin and Syriac translations.

\begin{tabular}{|c|c|c|c|c|}
\hline \multicolumn{3}{|c|}{ Revelation 21:19-20 } & \multirow{2}{*}{$\begin{array}{c}\text { S-Exodus 28, } 39 \\
\text { Syriac }\end{array}$} & \multirow{2}{*}{$\begin{array}{c}\text { S-Ezekiel 28:13 } \\
\text { Syriac }\end{array}$} \\
\hline Greek & Vulgate & Syriac & & \\
\hline "̋orıৎ & iaspus & yšph & $s w m q^{\prime}$ & srdwn \\
\hline 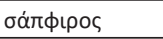 & sapphyrus & spyl' & wzrg' & wqrkdn' \\
\hline$\chi \alpha \lambda \kappa \eta \delta \dot{\omega} v$ & carcedonius & qrkdn & wbrq' & W'zmrgd' \\
\hline 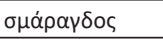 & zmaragdus & zmrgd' & șdyd' & wbrwl' \\
\hline$\sigma \alpha \rho \delta o ́ v u \xi$ & sardonix & srdwn wțpr' & wspyl' & wspyl' \\
\hline 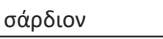 & sardinius & $s r d n$ & $w n q ' t$ ' & wyšpwn \\
\hline 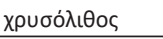 & chrysolitus & $k^{\prime} p d h b^{\prime}$ & qnkynwn & wqrwsț/ws \\
\hline 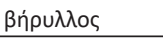 & berillus & $b r w l^{\prime}$ & wqrkdn' & wmrgnyt' \\
\hline 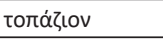 & topazius & țwpndywn & w'yn 'gl' & \\
\hline 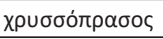 & chrysoprassus & krwsprs' & tršyš & \\
\hline úákıvӨos & hyacinthus & ywktws & $w b r w l^{\prime}$ & \\
\hline$\dot{\alpha} \mu \varepsilon \dot{\theta} \theta$ бо๐ & amethistus & 'mwtss & wyšph & \\
\hline
\end{tabular}

S, Syriac.

TABLE 20: Precious stones in Revelation 21:19-20 compared to the LXX-Exodus breastpiece lists.

\begin{tabular}{|c|c|c|}
\hline $\begin{array}{l}\text { Revelation } \\
21: 19-20\end{array}$ & $\begin{array}{l}\text { LXX-Exodus 28; } \\
\text { LXX-Exodus } 36\end{array}$ & Notes \\
\hline 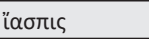 & 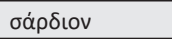 & - \\
\hline 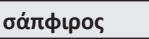 & 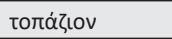 & 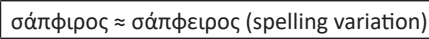 \\
\hline$\chi \alpha \lambda \kappa \eta \delta \dot{\omega} v$ & $\sigma \mu \alpha \dot{\rho} \rho \gamma \delta \delta^{\prime}$ & - \\
\hline 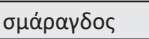 & $\not ̈ v \theta \rho \alpha \xi$ & - \\
\hline 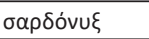 & 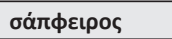 & - \\
\hline 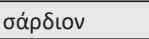 & 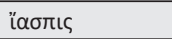 & - \\
\hline 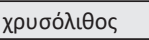 & $\lambda$ ıyúpiov & - \\
\hline 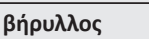 & 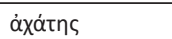 & 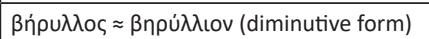 \\
\hline 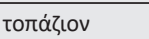 & $\dot{\alpha} \mu \varepsilon \dot{\theta}$ ибто & - \\
\hline 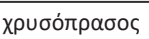 & 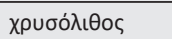 & - \\
\hline úókıvӨos & $\beta \eta \rho u ́ \lambda \lambda ı$ เov & - \\
\hline 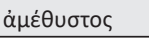 & óvúxıov & - \\
\hline
\end{tabular}

Note: Grey shading indicates stones that are represented both in Revelation 21:19-20 and in the LXX lists. Bold type indicates stones that correspond referentially in the two lists but exhibit slight spelling or morphological variants. The order of the stones in the two lists does not correspond at all.

LXX, Septuagint.

\section{Analysis of the Septuagint lists}

In this section, we return to the breastpiece of the high priest as translated by the LXX translator(s). We begin with the identification of the stones and then analyse the translation strategies of the LXX translator(s).

Based upon the analysis of Naudé and Miller-Naudé (2020), all 12 stones in the LXX are translations of the stones from MT-Exodus as indicated in Table 21 (following the MT order). There is referential identity between the Hebrew terms and their Greek equivalents, except in the case of ?ִּלם [aquamarine], which the LXX translator(s) rendered with the closest equivalent known to him, $\beta \eta \rho v i \lambda \lambda$ iov [beryl], ablue-green stone in the same mineral family as the aquamarine.

The LXX order follows that of MT-Exodus with respect to the first five stones and four additional stones, for a total of nine stones. The LXX follows the order of MT-Ezekiel with respect to one additional stone. A grand total of 10 stones correspond in order; only the last two stones of the LXX list do not correspond to either MT-Exodus or MT-Ezekiel (see Table 22).
TABLE 21: Identification of the stones.

\begin{tabular}{|c|c|c|c|}
\hline & $\begin{array}{l}\text { MT-Exodus 28:17-20 } \\
\text { MT-Exodus 39:10-14 }\end{array}$ & LXX-Exodus $\dagger$ & Identification \\
\hline \multirow[t]{3}{*}{ Row 1} & 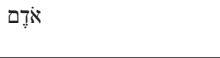 & 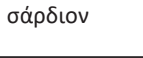 & $\begin{array}{l}\text { Carnelian or sardius, with a } \\
\text { reddish colour }\end{array}$ \\
\hline & 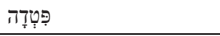 & 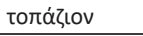 & Topaz, with a yellow colour \\
\hline & בדּרקסת & 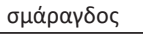 & Emerald, with a green colour \\
\hline \multirow[t]{4}{*}{ Row 2} & נפֶּך & $\alpha ̈ v \theta \rho \alpha \xi$ & $\begin{array}{l}\text { Malachite, with a dark green } \\
\text { colour }\end{array}$ \\
\hline & סַפְּריר & 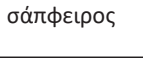 & $\begin{array}{l}\text { Lapis lazuli, with a dark blue } \\
\text { colour }\end{array}$ \\
\hline & 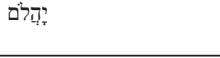 & - & $\begin{array}{l}\text { Aquamarine, a type of beryl, } \\
\text { with a turquoise colour }\end{array}$ \\
\hline & - & $\beta \eta \rho u ́ \lambda \lambda ı$ เov & Beryl, with a blue-green colour \\
\hline \multirow[t]{3}{*}{ Row 3} & לִשֶׁם & $\lambda$ ıpúpıov & $\begin{array}{l}\text { Hyacinth, with an orange } \\
\text { colour }\end{array}$ \\
\hline & نשְבוֹ & áxótns & $\begin{array}{l}\text { Agate, multicoloured with } \\
\text { white stripes }\end{array}$ \\
\hline & אַחְלָמָה & 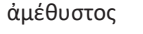 & Amethyst, with a purple colour \\
\hline \multirow[t]{3}{*}{ Row 4} & תַחרְשׁיש & 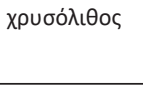 & $\begin{array}{l}\text { Chrysolite (peridot), with a } \\
\text { yellow-green colour (belongs } \\
\text { to the olivine mineral group) }\end{array}$ \\
\hline & 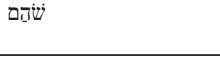 & óvúxıov & $\begin{array}{l}\text { Onyx, with a black or dark grey } \\
\text { colour with white stripes }\end{array}$ \\
\hline & 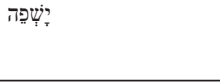 & i̊orıৎ & $\begin{array}{l}\text { Jasper, with a brownish-red } \\
\text { colour (late Hellenistic jasper is } \\
\text { green) }\end{array}$ \\
\hline
\end{tabular}

MT, Masoretic Text; LXX, Septuagint.

$\dagger$, Stones appear in MT order.

It is clear that the three identical renditions of the stones in LXX-Exodus 28; LXX-Exodus 36 and LXX-Ezekiel 28 display a 'normalising' translation strategy. The translator(s) of LXX Ezekiel normalised (or regularised) the MT list by adding the three stones missing in the MT and arranging the stones in the same order that was used by the translator(s) of LXX-Exodus. There is no reason to believe that the LXX translator(s) of Ezekiel had a different Hebrew Vorlage; rather the translator(s) of LXX-Ezekiel had access to the translation in LXX-Exodus. As described above (see Table 6), the LXX translator(s) changed the order of three stones in the Hebrew of Exodus by rotating them. However, why did the translator(s) of LXX-Exodus make minor changes to

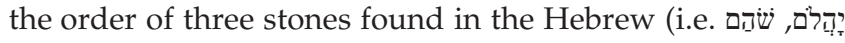
and the LXX?

We begin with a comparison of the colours of the stones in MT-Exodus and the LXX (compare Tables 23 and 24). 
TABLE 22: Order of LXX stones compared to MT-Exodus and MT-Ezekiel.

\begin{tabular}{|c|c|c|c|c|c|}
\hline & LXX reflects MT-Exodus & MT-Exodus 28:17-20; MT-Exodus 39:10-14 & LXX-Exodus; LXX-Ezekiel & MT-Ezekiel 28:13 & LXX reflects MT-Ezekie \\
\hline \multirow[t]{3}{*}{ Row 1} & & אדָדם & 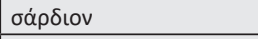 & אָדִדם & \\
\hline & & 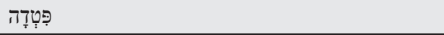 & 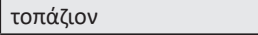 & פְְִּדָדה & \\
\hline & & וּבְרְקרת & $\sigma \mu \alpha \dot{\alpha} \alpha \gamma \delta$ ○ & 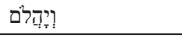 & \\
\hline \multirow[t]{3}{*}{ Row 2} & & 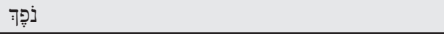 & 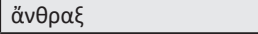 & 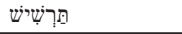 & \\
\hline & & סַפְּיר & 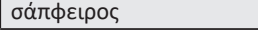 & שَהם & \\
\hline & & וּיְהּלם & 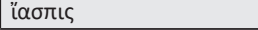 & 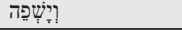 & \\
\hline \multirow[t]{3}{*}{ Row 3} & & ? לֶ? & 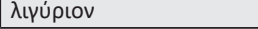 & סַפְּיר & \\
\hline & & 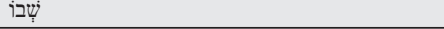 & áxátņ & & \\
\hline & & 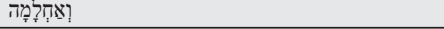 & $\dot{\alpha} \mu \varepsilon \dot{\theta} \theta$ vтоৎ & נפקֶּ & \\
\hline \multirow[t]{3}{*}{ Row 4} & & תַרְשׁׁיש & 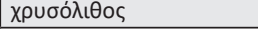 & וּרְרָקת & \\
\hline & & 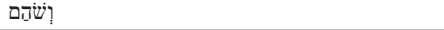 & 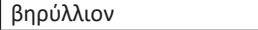 & & \\
\hline & & 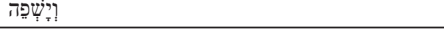 & óvúxıov & & \\
\hline
\end{tabular}

Note: Grey shading indicates identity (or close similarity) of stones with the lists in MT-Exodus and/or MT-Ezekiel.

MT, Masoretic Text; LXX, Septuagint.

TABLE 23: Colours of MT-Exodus stones.

\begin{tabular}{|c|c|c|c|}
\hline Column 3 & Column 2 & Column 1 & \\
\hline emerald-green & topaz-yellow & carnelian - red & Row 1 \\
\hline וּבְרְקֶֶת & 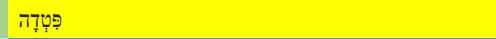 & אד & \\
\hline aquamarine - turquoise & lapis lazuli - blue & malachite - dark green & Row 2 \\
\hline וְיבהלם & סַפְּיר & נפקָד & \\
\hline 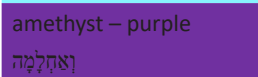 & $\begin{array}{l}\text { agate - multi-coloured } \\
\text { שָׁ }\end{array}$ & $\begin{array}{l}\text { hyacinth - orange } \\
\text { לֶ? }\end{array}$ & Row 3 \\
\hline 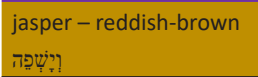 & $\begin{array}{l}\text { onyx - black/grey/red/brown with white stripes } \\
\text { וןשהם }\end{array}$ & $\begin{array}{l}\text { chrysolite - yellow-green } \\
\text { תמרְשִׁיש }\end{array}$ & Row 4 \\
\hline
\end{tabular}

TABLE 24: Colours of LXX stones (LXX-Exodus 28, 36; LXX-Ezekiel 28:13).

\begin{tabular}{|c|c|c|c|}
\hline Column 3 & Column 2 & Column 1 = MT & \\
\hline 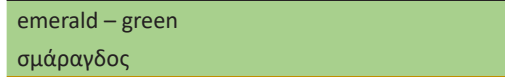 & 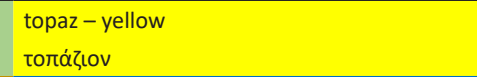 & 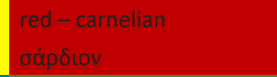 & Row $1=\mathrm{MT}$ \\
\hline 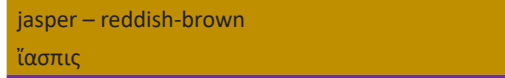 & $\begin{array}{l}\text { lapis lazuli - blue } \\
\text { бárффєроৎ }\end{array}$ & 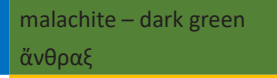 & Row 2 \\
\hline $\begin{array}{l}\text { amethyst-purple } \\
\dot{\alpha} \mu \varepsilon \dot{\theta u \sigma t o \varsigma}\end{array}$ & $\begin{array}{l}\text { agate - multi-coloured } \\
\text { áxátns }\end{array}$ & $\begin{array}{l}\text { hyacinth - orange } \\
\text { גıүúpıov }\end{array}$ & Row $3=\mathrm{MT}$ \\
\hline $\begin{array}{l}\text { onyx - black, grey, red, brown with white stripes } \\
\text { óvúxıov }\end{array}$ & $\begin{array}{l}\text { berryl - blue-green (or yellow, pink or white) } \\
\beta \eta \rho u ́ \lambda \lambda ı \text { เov }\end{array}$ & 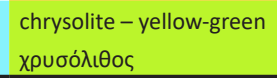 & Row 4 \\
\hline
\end{tabular}

MT, Masoretic Text.

Whilst it is impossible to know precisely the logic for the change in the arrangement of the stones by the LXX translator(s) of Exodus, one possibility relates to a rearrangement based upon the colours of the stones, probably on the basis of the symbolic values of the colours.

The appearance of precious stones is their most salient characteristic, and colour is the most important aspect of their appearance. Whilst colour in general is a visual cue for attracting and retaining attention as well as a cue that affects cognitive representation (Kauppinen-Räisänen \& Jauffret 2018; see also McLaury, Paramei \& Dedrick 2007), there are two lines of evidence from the texts examined in this study that help to substantiate the claim that the colour of the precious stones in these lists is of foremost importance. Firstly, when translators encountered the name of a stone in the incipient text that they did not know or that was no longer in fashion, they substituted a stone with a similar colour. As described above, this occurred in the LXX, Josephus and Revelation. The LXX substituted $\beta \eta \rho v i \lambda \lambda$ เov [beryl] for יָּיָלם [aquamarine]. Both stones are blue-green in colour; the fact that modern geologists assign them to the same superordinate family of stones (beryl) is not a premodern notion. Josephus substitutes $\sigma \alpha \rho \delta \delta^{\prime} v \xi \xi$

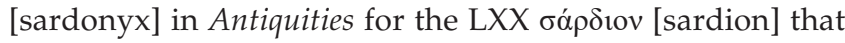
he used in Wars. Sardonyx is a type of onyx that is red or brown with white stripes; it is thus similar to sardion in colour. In Revelation, $\chi \alpha \lambda \kappa \eta \delta \omega \nu$ [chalcedony] is substituted for the LXX $\dot{\alpha} \chi \alpha \dot{\tau} \tau \varsigma$ [agate], the rendering of the Hebrew

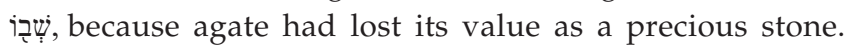
Chalcedony is similar to agate in its appearance and colour. The Syriac represents the stone in a similar way ( $q r k d n$ '). Revelation also substitutes the term $\chi \rho v \sigma o ́ \pi \rho \alpha \sigma o \varsigma$ [chrysoprase], a green stone, for the LXX rendering ö $v \theta \rho \alpha \xi$ [malachite] with a green colour. The second line of evidence for the importance of the colour of precious stones can be seen when translators encountered a stone for which there was no term in the language of the subsequent text they used a term to describe its appearance and specifically its colour, as described above. In the Syriac, the following examples occur: swmq' [the adjective 'red'], $\mathrm{rrg}^{\text {' [the }}$ adjective 'shining' or 'reddish'] and ' $y n$ ' $g l$ ' [calf's eye] to 
describe a gleaming or luminous precious stone. In the

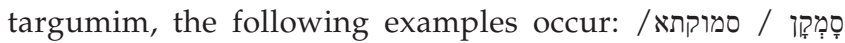

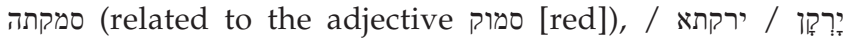

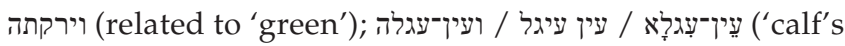

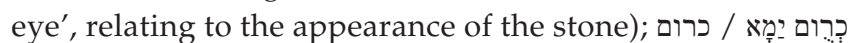
['] [י[ה / כרום ימא רבא 'related to a sea green colour, literally 'colour of the sea' or 'colour of the great sea'; note that even the word כרום is a loanword from the Greek abstract term

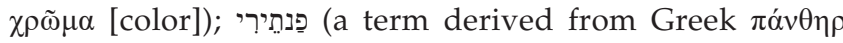
[panther] to refer to a spotted or multicoloured stone). We can thus safely infer that the colours of the precious stones (rather than their mineral content or hardness or any other characteristic) were their most important and salient feature.

Furthermore, the use of colours to convey symbolic values is extremely widespread across cultures and times; it is therefore not surprising to find that it was widespread across the ancient Near East and the Hellenistic world throughout the centuries.

In Egypt, colored precious stones used in jewelry had 'profound symbolic value' (Romano 2006:1606). Red stones were associated with blood (Aldred 1971:10), which could paradoxically imply either strength and vigour (blood as life) or death (Romano 2006:1606; see also Bianchi 1998:22 on the multiplicity of complementary and contradictory symbolic meanings in ancient Egypt). Green stones related to the emergence of new vegetation (Romano 2006:1606), blue stones related to water, and yellow stones related to sunshine (Aldred 1971:10). The 'classic trio' of precious stones that formed the basis for the colour schemes for jewelry in Egypt of the dynastic period included 'blood-red carnelian, the vivid blue-green of turquoise and the deep cerulean blue lapis lazuli' (Aldred 1971:16). Furthermore, the jewelry 'collars' of Egyptian royalty were often made of multiple rows of coloured stones (see the archaeological examples in Aldred 1971:114-126 and plates 7, 8, 10, 11, 46, $54,55,57,91,104,105){ }^{18}$

In the Hebrew Bible, there is no term attested for the abstract concept 'colour' (Corney 1982:657). In addition, there is 'a surprising dearth of references to specific colors, and of descriptions of things or locations as colorful', with two important exceptions: 'an extensive cluster of "color language" having to do with luxury, and another having to do with the environs and presence of God' (Smith 2006:701). As Smith notes, blue, purple and crimson are the colors of luxury textiles and also associated with the panoply of God's residences and service (Smith 2006:701). Blue represents water and sky, green represents vegetation, red represents blood and is associated with sacrifice, white is a symbol of purity, innocence, righteousness and redemption and purple represents royalty (Fleming 2012; Smith 2006). The use of reddish stones to symbolise life, health, affection and attractiveness continued in the Near East in the Arab periods (beginning in 640 CE) (Platt 2003:203).

Writing in the Roman period from the standpoint of Hellenised Judaism, Josephus explicitly identifies the colour symbolism that he believes plays a role in the vestments of the high priest (Antiquities Book 3, Chapter 7, Section 7) blue represents the heavens, sky or air; the white of the linen represents the earth; purple represents the sea because it is dyed by the 'blood of a sea shellfish' (the murex); and scarlet represents fire. These are the four elements. Gold represents the splendor with which all is interwoven. Josephus thus draws upon a Hellenistic view of colour symbolism in his explanation of the various colours. The association of the colours of the stones with theological symbolic values continues with the church fathers (for an overview, see Le Boulluec \& Sandevoir 2004:286-287).

The long tradition of colour symbolism throughout the ancient Near East and the connection of colour symbolism to precious stones, especially with respect to red, blue and green, provides evidence that the colour symbolism was also relevant to the arrangement of the precious stones in the high priest's breastpiece (pace Corney 1982:657).

Another viewpoint concerning the symbolic arrangement of the precious stones in the breastpiece comes from Philo (On Moses II:124-126), who sees the four rows of three stones each as related to the four zones of the zodiac, with each row representing one of the four seasons of the year and each zone (row) having three animals. Philo further indicates that the stones of the breastpiece all differ in their colours, no one resembling the colour of the other, just as each animal produces the colour that belongs to it in the earth and the air and the water.

Returning to the LXX rearrangement of the stones in the breastpiece, we posit two possible, partially interrelated, rationales for the rearrangement of the stones by the LXX translator(s). ${ }^{19}$ One possibility is that the LXX translator(s), like Philo, wanted to prevent any row from having two stones that were similar in colour. In that case, the movement of $\beta \eta \rho v ́ \lambda \lambda$ iov so that it was not in the same row as бó $\pi \varphi \varepsilon i \rho o \varsigma$ (two blue stones) and the movement of "í $\alpha \pi \mathrm{s}$ so that it was not in the same row as ovv́xiov (two red-brown stones) accomplished this goal. A second possibility is that the LXX translator(s) rearranged the breastpiece of the high priest so that each of the four rows contains a reddish stone, a green or blue stone and a yellowish stone. It does not seem that the LXX translator(s) is concerned with the symbolism of the four elements of Greek philosophy, at least as identified by Josephus, because such an arrangement would require each column to have four different coloured stones to represent the four elements, and that is clearly not the case. In

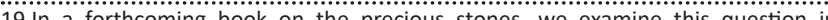
more detail using Peircean semiotics, in which colours may convey meaning by partaking in an iconic, indexical or symbolic relationship between the signifier partaking in an iconic, indexical or symbolic relationship between the signifier
and the signified (Peirce 1955; see also Almalech 2014; Caivano 1998; and the signified (Peirce 1955; s
Kauppinen-Räisänen \& Jauffret 2018). 
fact, the rearrangement by the LXX translator(s) resulted

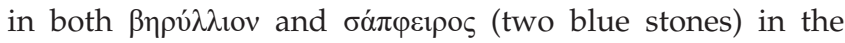

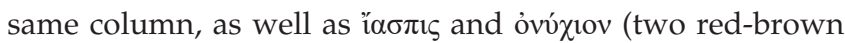
stones) in the same column. Instead, it seems that the LXX translator(s) is rather drawing upon the long ancient Near Eastern tradition of red symbolising blood (life), blue representing water and sky and green representing vegetation. The symbolism of yellow is less certain and might relate either to sunshine or perhaps to gold. The amethyst stone of the third row represents red, either because purple is composed of red and blue or because, as Josephus says, purple is like the blue sea dyed with the purple dye of the murex. The onyx in the fourth row is a stone that can be black or grey or red or brown with white stripes. By moving three stones, the LXX translator(s) achieved a rectangular arrangement of the 12 stones in which each row symbolised the red lifeblood, the fecundity of the earth with blue sky/ water or green vegetation, and yellow sunshine. The rotation of the stones by the LXX translator(s) to achieve his purpose is a technique used also by the writer of Ezekiel in rearranging the stones of the covering of the king of Tyre, and by the translator(s) of Neofiti in rearranging the stones of the breastpiece.

\section{Conclusion}

In this article, we have examined the various translations of the precious stones in the breastpiece of the high priest, with special focus on the earliest translation, that of the LXX. By using editorial theory (i.e. attention to individual manuscripts and translation traditions) and complexity theory (i.e. attention to a constellation of non-reductionistic, interlocking explanations), we have demonstrated that attention to the arrangement of the stones both with respect to their order and their patterns of coordination provides two metrics for determining the extent to which the translator(s) iconically translated (mimicked) the order and coordination of the Hebrew. In the case of translations later than the LXX, we were able to demonstrate the degree to which those translations depended primarily upon the Hebrew or upon the LXX. With respect to coordination, a syntactic feature that allows variation in each of the target languages examined here, the nearly imperceptible variations of coordination provide strong evidence of the direction of dependency on, or independence from, various incipient texts. With respect to the strategies of the translators for rendering the stones, we observed that translators place a premium on the rendering of the colour of the stone in cases where there is no referent, unless they transliterate the incipient text.

A major conclusion of this article is that the order of precious stones in the LXX rendering of the breastpiece is not random. The LXX lists do not reflect a different Vorlage. Nor are the LXX lists completely separate from those of the MT, as suggested by Harrell (2001) and Harrell et al. (2017). Rather, the translator(s) of LXX-Exodus attach(es) a different value to the arrangement of the stones, placing a higher value on colour symbolism than does the MT, which seems to have arranged the stones with respect to the order of the tribes, though the tribal arrangement itself is not explicitly indicated in the text. In order to highlight the colour symbolism, the translator(s) of LXX-Exodus made a few changes in the positions of three stones, which created a different arrangement of the whole and therefore a different symbolic effect for the breastpiece.

The MT-Ezekiel list of precious stones is a truncated list, which is reminiscent of the breastpiece of the high priest but reduced to three rows. Because the 12 tribes of the sons of Israel are not in view, the author or redactor of Ezekiel altered the arrangement of the stones in subtle ways that are at least aesthetic and probably symbolic. The LXX translator(s) of Ezekiel, however, normalised the list to bring it in line with that of LXX-Exodus, thus connecting the two passages.

The two lists of the precious stones of the breastpiece as provided by Josephus in his two works reflect, in the first instance, changes in time and place and thus subtle differences in the names of the stones. Josephus's lists, however, demonstrate that he was attentive both to the LXX and to the MT versions of the lists and made an attempt to mediate between them. His lists also attest to his uncertainty concerning the location of stones within a row, but not to the overall arrangement of the stones or their colour value within the breastpiece of the high priest.

The list of precious stones as the foundation of the New Jerusalem is clearly based upon the LXX list of the precious stones of the high priest. The precious foundation stones also symbolically represent the 12 apostles and thus connect back conceptually and symbolically to the 12 tribes of Israel. Because the foundation stones are not arranged in four rows of three stones, as is the breastpiece, the order of the stones in the breastpiece is not retained in the New Jerusalem. In addition, four new stones are introduced that are not in the LXX list, but they can be convincingly connected to rare or obsolete terms in the LXX list. The LXX list of precious stones as rendered by the translator(s) of Exodus thus played a critical role in the shaping of later traditions, even as those later traditions translated, substituted, updated and rearranged the list for later contexts, audiences and theological purposes.

\section{Acknowledgements}

An earlier version of this article was delivered at the Southern African Society for Ancient Near Eastern Studies at the University of KwaZulu-Natal, Pietermaritzburg, South Africa, on 16 September 2019. The authors are grateful for the comments of participants at the conference and especially Prof. Boaz Zissu. The authors also thank Megan Welman Purchase of the Department of Geology at the University of the Free State for her assistance with the scientific identification of the stones discussed in the article. The research for this article originated in the authors' research for the translation of precious 
stones in the 2020 Afrikaans Bible translation of the Bible Society of South Africa.

\section{Competing interests}

The authors declare that they have no financial or personal relationships that may have inappropriately influenced them in writing this research article.

\section{Authors' contributions}

C.L.M.-N. and J.A.N. contributed equally to this research article.

\section{Ethical considerations}

This article followed all ethical standards for research without direct contact with human or animal subjects.

\section{Funding information}

This work is based on research supported in part by the National Research Foundation of South Africa (Cynthia L. Miller-Naudé, UID 95926; Jacobus A. Naudé, UID 85902). The grantholders acknowledge that opinions, findings and conclusions or recommendations expressed in any publication generated by NRF-supported research are those of the authors, and that the NRF accepts no liability whatsoever in this regard.

\section{Data availability}

Data sharing is not applicable to this study as no new data were created or analysed in this study.

\section{Disclaimer}

The views and opinions expressed in this article are those of the authors and do not necessarily reflect the official policy or position of any affiliated agency of the authors.

\section{References}

Aldred, C., 1971, Jewels of the pharaohs: Egyptian jewelry of the dynastic period, Ballantine Books, New York, NY.

Almalech, M., 2014, 'Semiotics of colour', in Proceedings of the 12th World Congress of IASS/AIS, Sofia, Bulgaria, September 19, 2014, pp. 747-757.

Amar, Z., 2016, זיהוי אבני החושן ['Identifying the stones in the priestly breastplate'], בכל דיכוש דרכיך דעהו [Journal of Torah and Scholarship] 31, 7-27.

Bianchi, R.S., 1998, 'Symbols and meanings', in F.D. Friedman (ed.), Gifts of the nile: Ancient Egyptian faience, pp. 22-31, Thames and Hudson, London.

Caivano, J.L., 1998, 'Color and semiotics: A two-way street', Color Research and Application 23(6), 390-401.

Charles, R.H., 1920, A critical and exegetical commentary on the Revelation of St. John, 2 vols., T. \& T. Clark, Edinburgh.

Corney, 1982, 'Colors', in G.A. Buttrick (ed.), The interpreter's dictionary of the Bible, vol. 1, pp. 657-658, Abingdon, Nashville, TN.

Fleming, A.C., 2012, 'Symbolism of colors', in M.A. Beavis \& M.J. Gilmour (eds.), Dictionary of the Bible and Western Culture, pp. 94-95, Sheffield Phoenix Press, Sheffield.

Garfinkel, Y., Golub, M.R., Misgav, H. \& Ganor, S., 2015, 'The 'Išba'al inscription from Khirbet Qeiyafa', Bulletin of the American Schools of Oriental Research 373, 217-233. https://doi.org/10.5615/bullamerschoorie.373.0217

Gurtner, D.M., 2013, Exodus: A commentary on the Greek text of Codex Vaticanus, Septuagint Commentary Series, Brill, Leiden.

Harrell, J.A., 2001, 'Old Testament gemstones: A philological, geological and archaeological assessment of the Septuagint', Bulletin of Biblical Research 21(2) 141-172.
Harrell, J.A., Hoffmeier, J.K. \& Williams, K.F., 2017, 'Hebrew gemstones in the Old Testament: A lexical, geological and archaeological analysis', Bulletin of Biblical Research 27(1), 1-52.

Jastrow, M., 1967, A dictionary of the Targumim, the Talmud Bali and Yerushalmi, and the Midrashic literature, 2 vols., P. Shalom, Brooklyn, NY.

Kauppinen-Räisänen, H. \& Jauffret, M.-N., 2018, 'Using colour semiotics to explore colour meanings', Qualitative Market Research 21(1), 101-117. https://doi. org/10.1108/QMR-03-2016-0033

Le Boulluec, A. \& Sandevoir, P. (eds.), 2004, La Bible D'Alexandrie: L'Exode, Éditions du Cerf, Paris.

Liddell, H.G. \& Scott, R., 1978, A Greek-English Lexicon, rev. and augmented by H. S. Jones, 9th edn., Oxford University Press, Oxford.

Marais, K., 2019, A (Bio)semiotic theory of translation: The emergence of socialcultural reality, Routledge Advances in Translation and Interpreting Studies, Routledge, New York, NY.

McLaury, R.E., Paramei, G.E. \& Dedrick, D. (eds.), 2007, Anthropology of colour, Benjamins, Amsterdam.

Miller-Naudé, C.L. \& Naudé, J.A., 2018, 'Editorial theory and the range of translations for "Cedars of Lebanon" in the Septuagint', HTS Teologiese Studies/Theological Studies 74(1), a5059. https://doi.org/10.4102/hts.v74i1.5059

Misgav, H., Garfinkel, Y. \& Ganor, S., 2009, 'The ostracon', in Y. Garfinkel \& S. Ganor (eds.), Khirbet Qeiyafa, vol. 1: Excavation report 2007-2008, pp. 243-257, Israel Exploration Society, Institute of Archaeology, Hebrew University of Jerusalem, Jerusalem.

Naudé, J.A. \& Miller-Naudé, C.L., 2018, 'Lexicography and the translation of "Cedars of Lebanon" in the Septuagint', HTS Teologiese Studies/Theological Studies 74(3), a5042. https://doi.org/10.4102/hts.v74i3.5042

Naudé, J.A. \& Miller-Naudé, C.L., 2019, 'Sacred writings and their translations as complex phenomena: The book of Ben Sira in the Septuagint as a case in point', in K. Marais \& R. Meylaerts (eds.), Complexity thinking in translation studies: Methodological studies, pp. 180-215, Routledge Advances in Translation and Methodological studies, pp. 180-215, Routledge Advances in Translation and
Interpreting Studies, Routledge, London. https://doi.org/10.4324/9780203702017

Naudé, J.A. \& Miller-Naudé, C.L., 2020, 'The Septuagint translation as the key to the etymology and identification of precious stones in the Bible', HTS Teologiese Studies/Theological Studies 76(4), a6142. https://doi.org/10.4102/hts.v76i4.6142

Naudé, J.A. \& Miller-Naudé, C.L., forthcoming, 'Biblical plant hermeneutics and the translation of plants and plant products in the book of Ben Sira 24:13-17', in P.S. Marshall, J.D. Meade \& J.M. Kiel (eds.), Like nails firmly fixed: Essays on the text and language of the Hebrew and Greek scriptures, Peeters, Leuven.

Naudé, J.A., Miller-Naudé, C.L. \& Makutoane, T.J., forthcoming, 'The metaphorical and symbolic uses of flora in the Bible: Identification and translation of "hyssop" in P. Machinist, R. Harris, J. Berman, N. Samet \& N.A. Darshan (eds.), Ve-?Ed Ya Saleh (Gen 2:6), Writings from the Ancient World, Scholars Press, Atlanta.

Payne Smith, J., 1903, A compendious Syriac dictionary, At the Clarendon Press, Oxford. Peirce, C.S., 1955, Philosophical writings of Peirce, J. Buchler (ed.), Dover, New York, NY. Platt, E.E., 2003, 'Jewelry in the Levant', in S. Richard (ed.), Near Eastern archaeology: A reader, pp. 197-202, Eisenbrauns, Winona Lake, IN.

Reader, W.W., 1981, 'The twelve jewels of Revelation 21:19-20: Tradition history and modern interpretations', Journal of Biblical Literature 100(3), 433-457. https:// doi.org/10.2307/3265963

Romano, J.F., 2006, 'Jewelry and personal arts in ancient Egypt', in J.A. Sasson (ed.), Civilizations of the Ancient Near East, pp. 1605-1621, Hendrickson, Peabody, MA.

Schenkel, W., 2007, 'Colour terms in ancient Egyptian and Coptic', in R.E. McLaury, G.E. Paramei \& D. Dedrick (eds.), Anthropology of colour, pp. 211-228, Benjamins, Amsterdam.

Scheumann, J.R., forthcoming, 'A syntactic analysis of phrasal coordination in Biblical Hebrew', PhD thesis, University of the Free State.

Smith, D.M., 2006, 'Colors', in K.D. Sakenfeld (ed.), The new interpreter's dictionary of the Bible, vol. 1, p. 701, Abingdon, Nashville, TN.

Sokoloff, M., 2002, A dictionary of Jewish Palestinian Aramaic, 2nd edn., Bar Ilan University Press, Ramat-Gan.

Sokoloff, M., 2009, A Syriac lexicon: A translation from the Latin, correction, expansion, and update of C. Brockelmann's Lexicon Syriacum, Eisenbrauns, Winona Lake, IN

Walters, P., 1973, The text of the Septuagint: Its corruptions and their emendation, Cambridge University Press, Cambridge.

Waltke, B.K. \& O'Connor, M., 1990, An introduction to Biblical Hebrew syntax, Eisenbrauns, Winona Lake, IN.

Warburton, D.A., 2007, 'Basic color term evolution in the light of ancient evidence from the near East', in R.E. McLaury, G.E. Paramei \& D. Dedrick (eds.), Anthropology of colour, pp. 229-246, Benjamins, Amsterdam.

Whitfield, P., 2001, Astrology: A history, British Library, London.

\section{Biblical texts and versions}

Aland, B., Aland, K., Karavidopoulos, J., Martini, C.M. \& Metzger, B.M., 2012, Novum Testamentum Graece, 28th revised edn., Deutsche Bibelgesellschaft, Stuttgart.

Brooke, A.E. \& McLean, N. (eds.), 1909, The Old Testament in Greek according to the text of Codex Vaticanus, supplemented from other uncial manuscripts, with a critical apparatus containing the variants of the chief ancient authorities for the
text of the Septuagint, Exodus and Leviticus, vols. I and II, Cambridge University Press, London. 
Clarke, E.G., 1984, Targum Pseudo-Jonathan to the Pentateuch: Text and Concordance, Ktav, Hoboken, NJ.

Cohen, M., 1992, מקראות גדולות הכתר, Bar Ilan University Press, Ramat Gan.

Comprehensive Aramaic Lexicon Project, Hebrew Union College, Cincinnati, viewed 11 April 2020, from http://cal.huc.edu.

Elliger, K. \& Rudolph, W. (eds.), 1997, Biblia Hebraica Stuttgartensia, Deutsche Bibelgesellschaft, Stuttgart.

Levy, B.B., 1986, Targum Neophyti 1: A textual study, University Press of America, Lanham, MD.

Mulder, M.J. (ed.), 1993, The Old Testament in Syriac according to the Peshitta Version, Part III Fasc. 3. Ezekiel, Peshițta Institute, Brill, Leiden.

Rahlfs, A. \& Hanhart, R. (eds.), 2006, Septuaginta: Id est Vetus Testamentum Graece iuxta LXX interpretes, rev. edn., Deutsche Bibelgesellschaft, Stuttgart.

Sperber, A., 1992a, The Bible in Aramaic: The latter prophets according to Targum Jonathan, Brill, Leiden.
Sperber, A., 1992b, The Bible in Aramaic: The pentateuch according to Targum Onkelos, Brill, Leiden.

Ter Haar Romeny, B. \& Van Peursen, W.T. (eds.), 2016, The Old Testament in Syriac according to the Peshitta Version, Part 1 Fasc. 1. Preface.-Genesis; Exodus, Peshitta Institute, Brill, Leiden.

Ulrich, E. (ed.), 2013, The Biblical Qumran scrolls: Transcriptions and textual variants, 3 vols., Brill, Leiden.

Von Gall, A.F. (ed.), 1918, Der Hebräische Pentateuch der Samaritaner, Alfred Töpelmann, Giessen.

Weber, R. \& Gryson, R. (eds.), 2007, Biblia Sacra: luxta Vulgatam Versionem, 5th edn., Deutsche Bibelgesellschaft, Stuttgart.

Wevers, J.W., 1991, Septuaginta: Vetus Testamentum Graecum, Exodus, vol. 2,1, Akademie der Wissenschaften in Göttingen, Vandenhoeck \& Ruprecht, Göttingen.

Ziegler, J., 2006, Septuaginta: Vetus Testamentum Graecum, Ezekiel, vol. 16,1, Akademie der Wissenschaften im Göttingen, Vandenhoeck \& Ruprecht, Göttingen. 